
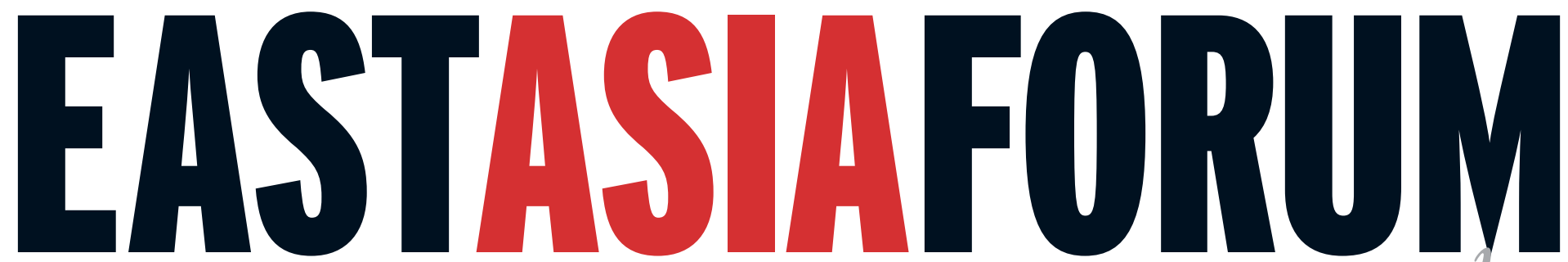

ECONOMICS, POLITICS AND PUBLIC POLICY IN EAST ASIA AND THE PACIFIC

Vol.8 No.1 January-March $2016 \$ 9.50$
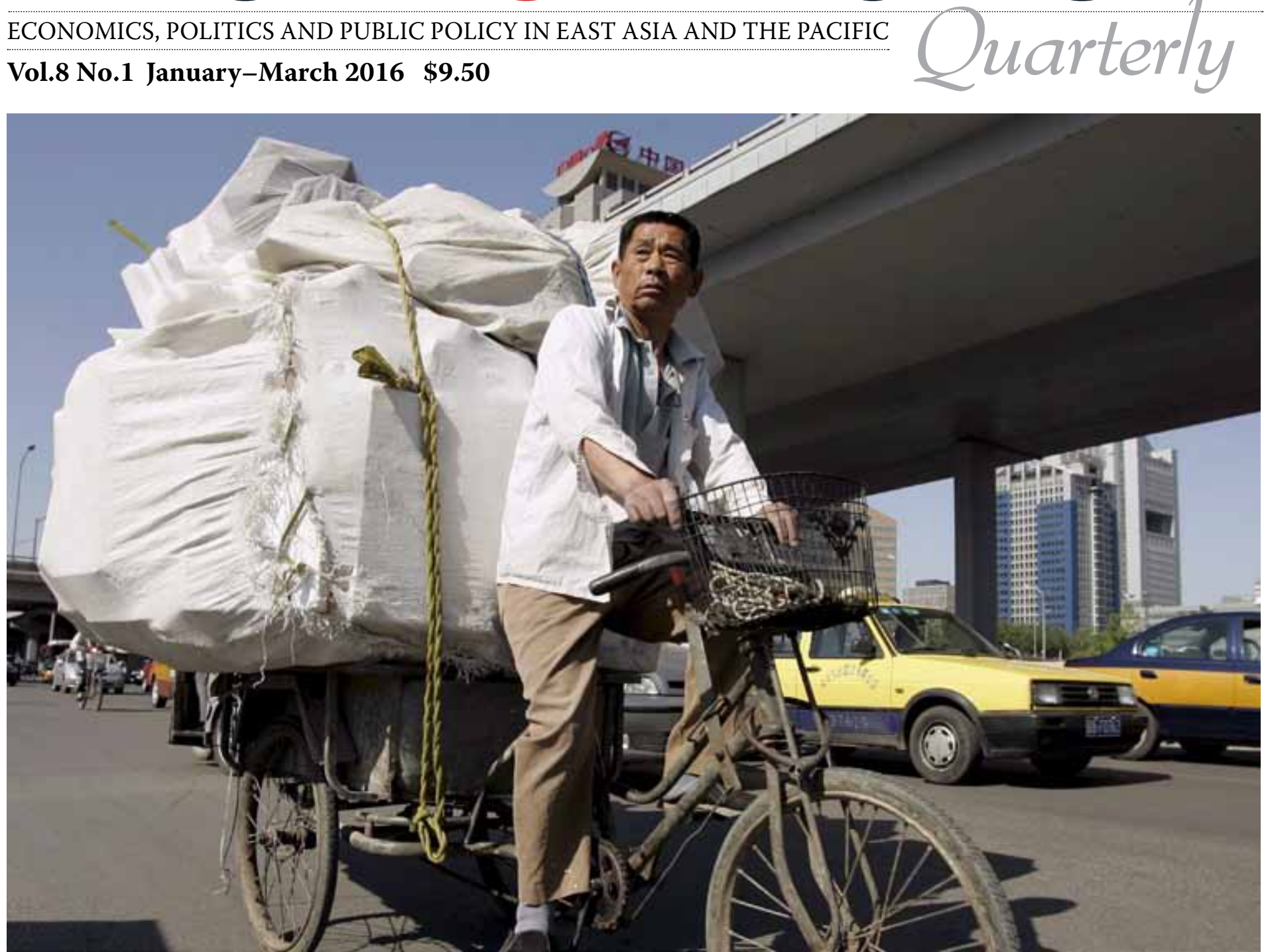

\title{
Stuck in the middle?
}

Indermit Gill and Homi Kharas Can Asia keep growing through middle income?

Yiping Huang Change needed for China to continue its steady climb

David Dollar What institutions do countries need for growth?

ASIAN REVIEW: Kay Kitazawa - Japan's crisis infrastructure still lacking Wing Thye Woo - Integration can keep the region above US-China fray 


\section{EASTASIAFORUM \\ Ouarterly \\ ISSN 1837-5081 (print) \\ ISSN 1837-509X (online)}

\section{From the Editors' desk}

Most of the world's population lives in middle-income countriesneither very rich nor very poor.

While middle-income countries are full of economic opportunities, the way up to higher incomes and living standards is not straightforward. Homi Kharas and Indermit Gill coined the term 'middle income trap' a decade ago to describe the hazards. The aphorism caught on, a worry for policymakers and a puzzle for debate among the analysts.

To get out of the middle income trap countries have to shift from lowskilled to high-skilled, innovative growth industries. That seems simple enough, but what do they need to do to make that transition? Education, how it's delivered and to whom are clearly critical parts of the story, but how is an innovative economy created?

Putting the right institutions in place is at the heart of long-run improvement in living standards. But the institutions that helped poor countries reach middle income are clearly not necessarily those that are needed to grow out of the trap. As innovation takes a more central role, institutions that constrain economic (and perhaps political) freedoms, for example, are not likely to foster creativity or entrepreneurship.

Middle income can be achieved through adopting other people's technology and creating policy settings that reap the benefits from specialising in international markets. Beyond middle income, the institutional foundations for open financial markets, governance intolerant of economic patronage and supportive of risk-taking and entrepreneurship are required.

Demography also has far-reaching consequences for the trajectory of national incomes. A rising young labour force is a valuable but fleeting asset. Ageing populations present unprecedented challenges, even for those at the top like Japan.

The essays in this issue of $E A F Q$, which derive from the soon-tobe-released 37th Pacific Trade and Development Conference volume edited by Francis Hutcheson and Sanchita Basu Das, bring together the field's most prominent voices to explore these issues that press upon the prospects for Asia today. And as well, our Asian Review includes essays on the lessons from Fukushima, the geo-political consequences of China's rise, Australia's leaders over the years and their approach to Asia.

\section{Peter Drysdale and Shiro Armstrong}

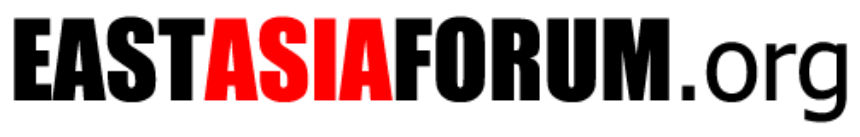

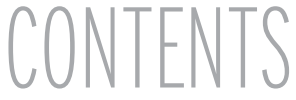

\section{INDERMIT GILL AND HOMI KHARAS \\ Can Asia keep growing through middle income?}

\section{EMMANUEL JIMINEZ AND}

ELIZABETH M. KING

Middle-income countries need to learn how to learn

\section{HAL HILL AND HARYO \\ ASWICAHYONO}

Policy reform can restore Indonesia's pace of growth

\section{NAOHIRO YASHIRO}

Is Japan caught in an upper income trap?

\section{YIPING HUANG}

Change needed for China to continue its steady climb

\section{KAY KITAZAWA}

ASIAN REVIEW: Five years on, Japan's crisis response infrastructure is still lacking

\section{WING THYE WOO}

ASIAN REVIEW: Integration can keep region above the US-China fray

\section{PETER HAYES AND ROGER \\ CAVAZOS}

ASIAN REVIEW: North Korea: more threats and brinkmanship

\section{FRANK BONGIORNO}

ASIAN REVIEW: Australian leaders' conceptions of Asia

\section{HUGH WHITE}

ASIAN REVIEW: Can Asia break free of great-power dynamics?

\section{JAMES RIEDEL AND PHAM \\ THI THU TRA \\ Growth engines and development traps}

27 SHEKHAR SHAH AND RAJESH

\section{CHADHA}

Why India's policymakers need to fire on all cylinders

\section{DAVID DOLLAR}

What institutions do countries need to keep growing?

30 SHIRO ARMSTRONG AND TOM
WESTLAND
Middle-income nations must learn to
trust the market




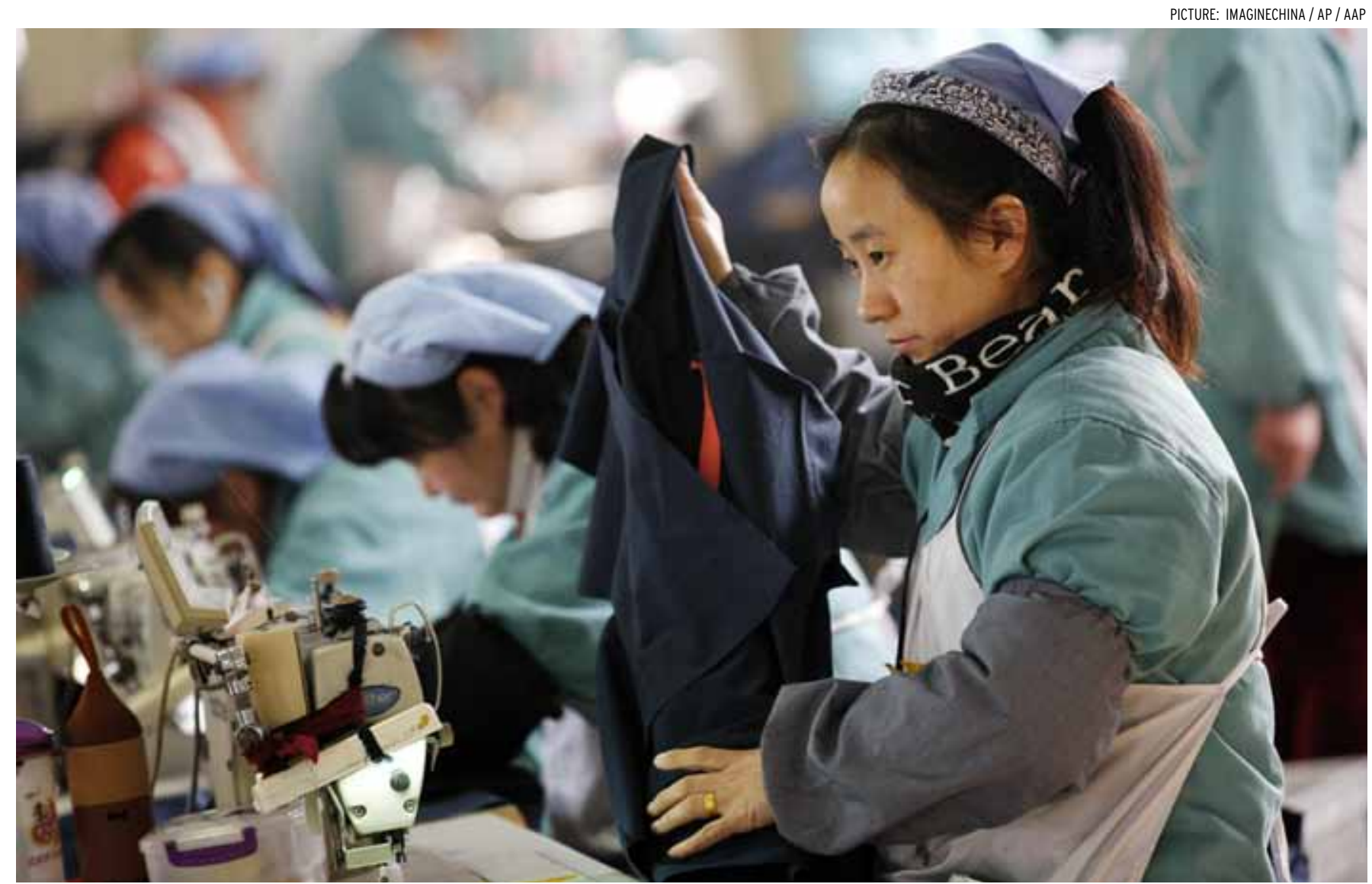

Workers making clothes for export at a factory in Huaibei city, China: countries that have joined global value chains have seen productivity rise.

\section{Can Asia keep growing through middle income?}

INDERMIT GILL

AND

HOMI KHARAS

\section{A}

BOUT a decade ago we

observed that there was no easily communicable growth strategy that we could recommend to policymakers in the middle-income economies in Asia.

At that time the China export juggernaut was accelerating. With wage levels that had already risen as a result of a successful transition from low-income to middle-income status, many East Asian economies were becoming uncompetitive with China in labour-intensive manufacturing. Economic policymakers began to wonder where the growth their countries needed to graduate from middle-income status to high-income status might come from.

In describing the problem, we coined the term 'middle income trap'. To us, the middle income trap was as much the absence of a satisfactory theory that could inform development policy in middle-income economies as the articulation of a development phenomenon. It was a trap of ignorance about the nature of economic growth in middle-income countries: mainstream economics addressed the problem in high-income economies, and development theory attempted to understand the growth problem in low-income countries. Since three out of four people in the world lived neither in advanced economies nor low-income countries, this was not a small gap.

To our surprise, the phrase 'middle 


\section{EASTASIAFORUM} EDITORIAL STAFF

\section{Issue Editors}

Peter Drysdale, Head, East Asia Forum and East Asian Bureau of Economic Research at the Crawford School of Public Policy, ANU.

Shiro Armstrong, Director, AustraliaJapan Research Centre and Executive Director, EAF and EABER, Crawford School, ANU.

\section{Series Editors}

Peter Drysdale, Crawford School of Public Policy, ANU.

Shiro Armstrong, Crawford School of Public Policy, ANU.

\section{Editorial Staff}

Coordination: Sam Hardwick, Mark Fabian.

Editing: Alison Darby, Patrick Deegan, Catherine Yen, Stephen Norman, Liam Gammon, Rosa Bishop, Sam Hardwick, Michael Wijnen ANU.

Editorial Advisers: Peter Fuller, Max Suich.

Production: Peter Fuller, Words \& Pics. Original design: Peter Schofield.

Email Peter.Drysdale@anu.edu.au, Shiro.Armstrong@anu.edu.au.

COVER: Transport old and new on the streets of Beijing. PICTURE: Michael Reynolds / EPA / AAP.

The views expressed are those of the individual authors and do not represent the views of the Crawford School, ANU, EABER, EAF, or the institutions to which the authors are attached.

\section{ANU PRESS}

Published by ANU Press The Australian National University Canberra ACT 0200, Australia

Email: anupress@anu.edu.au Web: http://press.anu.edu.au income trap' immediately became popular among policymakers and development specialists. In East Asia, the Great Recession of 2008 rocked the confidence of economic policymakers and triggered a big debate on what to do next. By mid-2009, Malaysian policymakers, including Prime Minister Najib, had started to use the phrase in speeches and even launched a National Economic Advisory Council to elaborate a plan on how to escape the trap. In China, from 2010 onwards, officials in charge of the preparation of the 12th Five Year Plan 2011-2016, including Liu He, started to debate whether China was becoming vulnerable to the middle income trap.

Ten years have passed, and there is growing discussion about whether the middle income trap exists and, if so, what its characteristics are and how countries might 'escape' it and reach high-income levels. So what have we learnt since?

The importance of trade liberalisation for growth in middleincome countries remains vital; countries and firms that have joined global value chains have seen productivity growth. Countries that are competitive in sectors where economies of scale are present are the most likely to experience substantial gains from opening up.

Successful middle-income countries are also likely to be ones that encourage innovation. Openness to trade plays a big role in increasing competition and thereby inducing innovation and technological transfer. So too do new capital investments, as well as research and development: these are also likely to lead to the diffusion of more advanced technologies.

The quality of financial markets and capital market liberalisation are also likely to be important for middle-
Openness to trade plays

\section{a big role in increasing}

\section{competition and thereby}

inducing innovation and

technological transfer

income countries. We recommended that middleincome countries move towards more flexible exchange rates, while developing local financial markets to provide firms with more opportunities to hedge foreign exchange risk. As it happens, middleincome countries have been moving steadily in this direction, restoring monetary policy as an instrument of macroeconomic management.

And we emphasised the role that dealing with urbanisation and agglomeration, tackling inequality and rooting out corruption might play in a successful economic strategy for middle-income countries.

But in hindsight, there are other areas we did not emphasise, but should have. There are three issues to which leaders in middle-income countries ought to pay attention.

One of these is the impact of demographic shifts. Some studies suggest that a whole one-quarter of China's growth over the past three decades has been the result of its demography. And many middle countries, like Nigeria or India, are hoping that a generation of young people entering the labour force will provide them with a demographic dividend; others worry that the dividend has now run its course. The 


\section{EDUCATION}

danger for all middle-income countries is that of growing old before they get rich.

Another task that faces middleincome countries is to foster a climate of entrepreneurship. This is subtly different from the issue of innovation. A balanced set of skills-including but not restricted to the traditional science and technology skills favoured by some middle-income countries-is needed to produce a generation of entrepreneurs that will turn ideas into new businesses. China already faces this imperative.

The role of external commitments and regionalism also deserves attention. Regional institutions can help to secure the long-term economic trajectory of middle-income countries by pre-committing countries to liberalising reform. In a world in which the World Trade Organization process has stalled, these external commitments are likely to be regional in nature. This might help several middle-income countries in a region to escape the trap together, and it is for this reason that we are optimistic about the poorer countries in ASEAN such as Cambodia, Laos and Myanmar.

There is no doubt that the 'middle income trap' has captured the imagination of policymakers around the region. Although the idea itself is still being sorted out, what is clear is that middle-income countries will have to think hard about the changes they need to put in place if they are to make the transition to high income. EAFO

\section{Indermit Gill is Director for}

Development Policy in the Office of the Chief Economist of the World Bank.

Homi Kharas is a Senior Fellow and Deputy Director for the Global Economy and Development Program at the Brookings Institution, Washington $D C$.

Middle-income countries need to
learn how to learn

EMMANUEL JIMENEZ

AND

ELIZABETH M. KING

NVESTMENT in human capital

through education, partly by the government, is almost universally thought to be a precondition for sustainable growth. For Asian countries that can no longer rely on factor accumulation to underpin their continued economic development, improving the quality of national education systems has become of paramount importance.

The historical experience of the Asian economies that have grown to high income suggests that education holds the key to graduation from middle-income levels. And falling fertility rates opened up a window of opportunity to take better advantage of its benefits as the demographic profile in these countries changed dramatically.

The East Asian 'tigers' undoubtedly achieved impressive increases in school enrolments. In 1950, about one in two people in these countries had no education; by 2010, this figure had shrunk to less than one in ten. Average years of schooling of the population aged 15 and over increased by about two years, much more than in other developing countries. Indeed, in some tiger economies (like South Korea and Singapore) there is even concern about 'overeducation' as enrolments have soared at the tertiary level.
There has been a similarly impressive increase in enrolment in the so-called 'tiger cubs', Malaysia and Thailand, although test scores in these countries lag far behind their more developed neighbours in the region. One particular standout in the region is poorer Vietnam, where students' maths and reading comprehension scores are about on a par with South Korea's, according to the 2012 OECDPISA results.

Avoiding the middle income trap means countries must move from competing on the low-skill margin to the high-skill margin. But what does this mean? There are three salient types of skills: cognitive, non-cognitive and creative. Increasing school enrolments and test scores reflect a concentration on cognitive skills, but non-cognitive and creative skills (popularly referred to as the '21st century skills') will likely be just as important in future.

Due to technological and market changes, the skills that employers demand have shifted in developed countries, including in the tiger economies, from skills for manual, routine work to skills for manual, nonroutine tasks, and even more analytical non-routine work. This means that education systems in middle-income countries will need to foster not only the cognitive and technical skills that have traditionally been the focus of education systems in developing countries, but also critical thinking, 


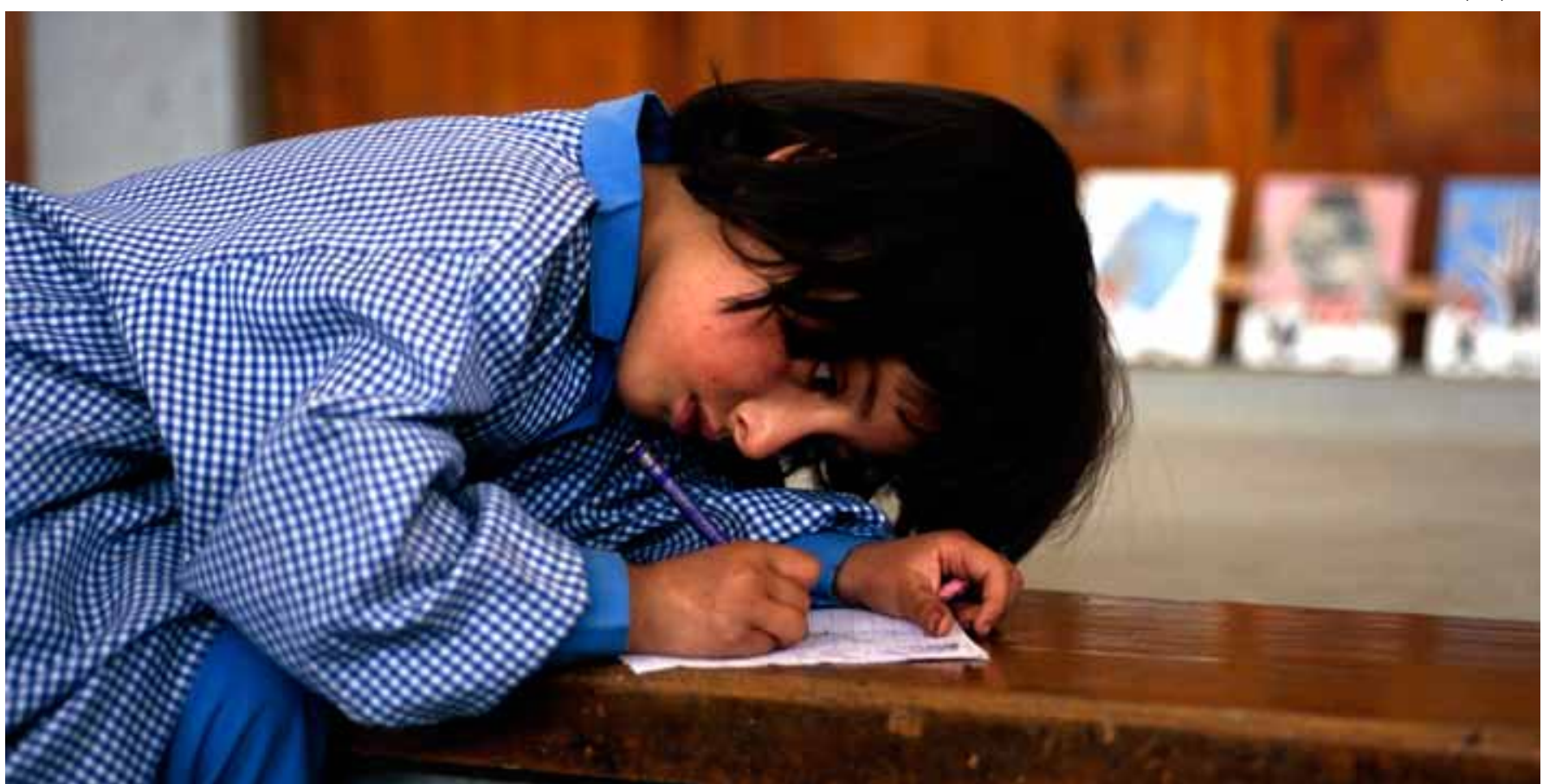

Practising writing at a school in Gilgit, northern Pakistan: experience suggests that education holds the key to nations graduating from middle-income status.

teamwork, problem-solving and communication skills.

Contrary to some popular wisdom, there is good evidence that East Asian education systems do not lag behind when it comes to instilling the ability to solve problems creatively-in fact, students in Singapore, South Korea, Japan and Taiwan, as well as students in Hong Kong, Shanghai and Macao, outperform their peers internationally on problem-solving tests. And although patenting activity is an imperfect measure of creativity, it is nonetheless interesting to note the strong performance of the tiger economies in generating patents. All of this suggests that middle-income countries around the region ought to consider the institutional and educational settings that have allowed their neighbours to improve the quality of education offered to their young people.

In general, the policies that will help middle-income countries build their stock of human capital vary from country to country. But while there is no universally applicable prescription, policymakers should draw heavily on the evidence base that already exists. New interventions should be subject to rigorous impact evaluations, especially for programs that target non-cognitive and creative skills for which there is very little hard empirical evidence for programme effectiveness.

\section{J} UST as creativity is important for students and future workers, innovation in the kinds of policies used to improve educational outcomes ought to be encouraged. For example, policy interventions to improve the quality of education in the Asia Pacific need not be necessarily focused tightly on traditional school expenditures. Health interventions, like giving free reading glasses and micronutrients to low-income children, have been shown in random trials to improve scores at relatively low cost. Similarly, providing educational inputs like laptops and reading material to children has been shown to improve educational outcomes in randomised trials.

Countries that have succeeded in 'breaking through' middle-income status have done so not only by expanding the opportunities for more human capital accumulation as measured conventionally by years of schooling, or amounts of money spent on education-they have also invested heavily in the quality of education and have kept a close eye on monitoring learning outcomes. In the future, the hurdle for making the jump may be altogether higher, with the need for creativity becoming paramount. Countries that fear getting stuck at middle-income levels need to follow the evidence-and learn how to learn. EAFO

Emmanuel Jimenez is the Executive Director of the International Initiative for Impact Evaluation.

Elizabeth M. King is a non-resident senior fellow at The Brookings Institution, Washington DC. 
HAL HILL AND

HARYO ASWICAHYONO

B ASED on World Bank measures, Indonesia became a middleincome country in 2004. Indonesia's growth rates, while superior to those of most developing countries, remain below those of East Asia's most dynamic economies. So why hasn't the country grown faster still and why does growth appear slower in the democratic era than in Suharto's time?

Few countries have experienced such dramatic changes in economic fortunes and political governance as Indonesia. A 'chronic economic dropout' in the mid-1960s, it took a remarkable turnaround and three decades for Indonesia to join East Asia's miracle economies in the 1990s. But having graduated to middleincome status-when rapid, East Asian style economic development seemed assured-Indonesia experienced another discontinuity: the Asian financial crisis. This collapse was accompanied by, and indeed triggered, a political crisis, with the sudden end of the 32-year rule of president Suharto in 1998. The economy seemed in free fall.

But, as in the mid-1960s, the doomsayers were wrong. The economy quickly bounced back and Indonesia rapidly emerged as Southeast Asia's most vibrant democracy, in which 'big bang' decentralisation devolved much administrative, financial and political power to sub-national governments. It was one of the most comprehensive and rapid reconstructions of a country's political institutions and processes in recent times, with only a brief loss of economic momentum.

With this record of economic and political dynamism, the notion of a middle income trap in Indonesia hardly appears relevant. If growth rates from the last 15 years continue, Indonesia will graduate to the highincome group within half a century.

At the same time there are some key, if unquantifiable, challenges holding back stronger growth in Indonesia.

The Indonesian public has long been reluctant to embrace liberalism and globalisation. On this issue, the pendulum swung from global disengagement in the early 1960 s to an open regime in the late 1960s to growing state intervention during the 1970s oil boom before major deregulation from the mid-1980s. With persistently pro- and anti-reform currents, Indonesia has remained reasonably open since this time.

But the country's rising economic nationalism has intensified protectionist pressures. This policy stance, combined with declining commodity prices since 2012, has resulted in indifferent export performance in recent years. Meanwhile, Indonesia continues to underperform in the crucial area of connecting to global value chains. These account for almost half of trade within ASEAN, but Indonesia remains a relatively minor participant.

The reasons for this under- performance are well known and amenable to policy intervention. Participating in these chains requires open trade and investment regimes, highly efficient logistics infrastructure and competitive labour inputs. In these three key areas, Indonesia lags.

In education, Indonesia has achieved impressive gains since the 1970s. The country is now close to reaching universal literacy for its school-aged population and there is a general commitment to funding, with a 20 per cent mandate on the government's budget. But according to most comparative 'quality' indicators, such as international examinations, the country lags in other areas. High post-primary dropout rates remain a problem.

M AJOR challenges in higher education will become more pressing as Indonesia progresses through the ranks of the middleincome group. This sector is growing rapidly but the government spends only 0.3 per cent of GDP on its historically state-operated universities. While most of the growth must thus come with private involvement, the government remains ambivalent about deregulating and internationalising the system. The quality of tertiary education is highly variable, with no institutions featuring prominently in international comparisons.

Educational challenges are compounded by related labour market problems of weak formal sector employment and skill mismatches. 


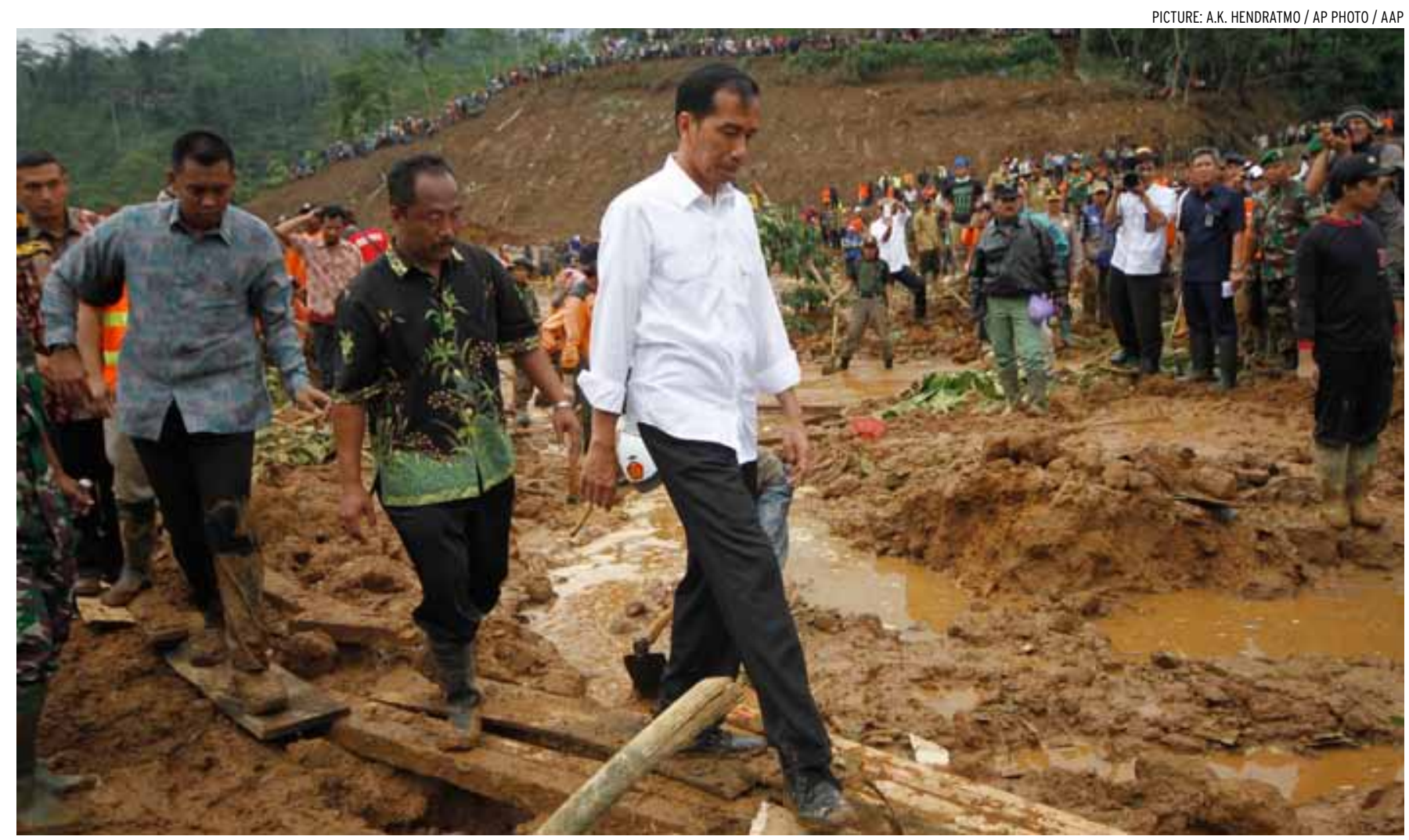

President Joko Widodo inspects the site of a landslide in Jemblung, Java, in December 2014. Underinvestment has contributed to low-quality infrastructure.

During 1966-96, formal sector employment and modern sector wages grew strongly. The Asian financial crisis resulted in a sharp fall in formal employment and real wages. Democratisation unleashed powerful 'pro-labour' sentiments. Increased labour market regulation and slower growth resulted in anaemic formal sector employment growth, especially in the manufacturing sector, which had been a key source of dynamic growth. As a result, Indonesia lost competitiveness in international markets for labour-intensive manufactures.

Then there's infrastructure. Here Indonesia's problems are intensively studied and of high political priority. The problem is that inter-island transport costs are very high. This pushes up the general cost structure, particularly for remote areas, leading to large inter-regional price differences. On logistics performance, Indonesia lags all ASEAN neighbours bar the Philippines.

Underinvestment has contributed to the low quality and quantity of infrastructure. As a percentage of GDP, Indonesia's infrastructure expenditure is about half of that in the Suharto era and in other high-growth East Asian economies. Regulatory constraints on competition and efficient service provision compound these problems, as does a strong post-financial-crisis aversion to foreign borrowing, which means that successive governments have not availed themselves of much of the long-term concessional finance on offer.

From a longer-term perspective, Indonesia is in the early stages of establishing a democratic consensus around the institutions needed for a prosperous, equitable and internationally oriented economy.
Substantial challenges remain in the country's legal system, which are closely tied to fighting corruption, increasing bureaucratic efficiency and improving local-level governance.

Indonesia has only recently graduated to middle-income status. While moderately strong economic growth means that is not in any sense 'trapped', it will have to overcome the problems holding back its growth as it moves up through the middleincome ranks. Fortunately, all of these issues are amenable to relatively straightforward policy reforms. EAFQ

Hal Hill is a Professor of Economics at The Australian National University. Haryo Aswicahyono is a researcher in the Department of Economics at the Centre for International and Strategic Studies (CSIS), Jakarta. 


\section{DEMOGRAPHIC OPPORTUNITIES?}

\section{Is Japan caught in an upper income trap?}

NAOHIRO YASHIRO

J APAN'S economy is stagnant and has been so for quite some time now. It looks as if Japan is now in the 'upper income trap'. In comparison with its 10 per cent real GDP growth rate between 1950 and 1960 and 4 per cent growth rate between 1970 and 1980, Japan has only managed an average growth rate of 1 per cent since the early 1990s. This declining trend has been driven by Japan's considerable demographic challenges.

Japan's dependency ratio-that is, the proportion of non-workingage to working-age people in the total population-was in decline up until the 1970s, which led to a 'population bonus' or demographic dividend and high GDP growth. It eventually stabilised in the 1980 s, as did GDP growth. But since the 1990s the dependency ratio has been on the rise again, leading to a period of 'population onus' and economic stagnation.

Population ageing is a significant demographic issue for Japan and a common feature among developed economies. With high GDP per capita, people live longer and choose to invest more in their children's education. Often this results in couples deciding to have fewer children and, therefore, the fertility ratio declining. As the share of elderly people to the total population increases so does the social security burden on the working generation, which can discourage investment.
There are several factors that exacerbate the negative impacts of population ageing in Japan, compared with other developed countries.

One factor is the age-specific nature of Japanese workplaces. In large companies, employees are promoted based on their years of service to a particular firm and wages are set based on their seniority. This system has become increasingly costly due to the increasing proportion of senior employees in firms. Combined with the commitment to long-term employment, this means that Japanese firms have heavy fixed employment costs that gradually squeeze profits.

Although the labour force participation rate of the elderly is particularly high in Japan, most

With appropriate

structural reform, the

declining labour force

growth and ageing

population can actually

be harnessed as potential

sources of future

economic growth large firms still require employees to retire at 60 years of age. This not only constitutes age-based discrimination, but is also a waste of human resources. Most elderly workers are re-employed in the same firm on a fixed-term contract at least to age 65 , but they are generally not assigned to responsible positions. The increase in elderly workers compounds the high ratio of non-regular workers.

Japanese women are similarly poorly utilised in the labour market, despite their high education levels. In 2015, the female labour force participation rate of 25- to 44-yearolds was 74.4 per cent compared with 95.3 per cent for males. This reflects a typical lifecycle pattern where women leave the labour force to rear children. The gap in human capital investment in women, compared with men, is a major reason for why just 10 per cent of managers in Japanese companies are female.

On top of this, Japan still maintains a negative attitude towards foreign workers despite its sharply diminishing labour force. The basic immigration policy accepts professional workers but refuses to embrace unskilled workers. This policy is inconsistent with Japanese firms' needs and has resulted in de facto unskilled foreign workers-who are employed as 'trainees'-having to return unwillingly to their home countries after three to five years. This is undesirable for both the foreign workers and the firms employing them.

Economic growth does not depend 
on demographic factors alone and long-term economic stagnation is avoidable. With appropriate structural reform, the declining labour force growth and ageing population can actually be harnessed as potential sources of future economic growth.

One useful reform would be to enforce equal pay for equal work.

Prime Minister Shinzo Abe has in fact become an advocate of this. Of course, the application of such a reform should be flexible. Mechanically applying the principle of wage equality is not necessarily the answer. Rather, it may be sufficient to simply ask the employer to justify the existence of wage differentiation, including, for example, across different age groups. This would shift the burden of proof from the employees to the employers and provide an important step towards pay equality.

Current immigration policy also needs to be revised. Unskilled foreign workers coming to Japan to undertake traineeships have to be accepted as skilled workers after the completion of their training period. Currently foreign trainees fall under the Official Development Aid program, which provides training to foreigners who will work for their own countries. Recently there has been some progress towards this reform; foreign workers are now allowed to undertake household activities within National Strategic Special Zones.

While Japanese growth is stalled, persistent economic stagnation is not a given. But breaking the upper income trap will require Japan to overcome entrenched institutional barriers and harness its ageing population. If Japan is to succeed, strong political leadership is crucial. EAFF

\section{Naohiro Yashiro is a visiting professor} of economics at the Showa Women's University, Tokyo.

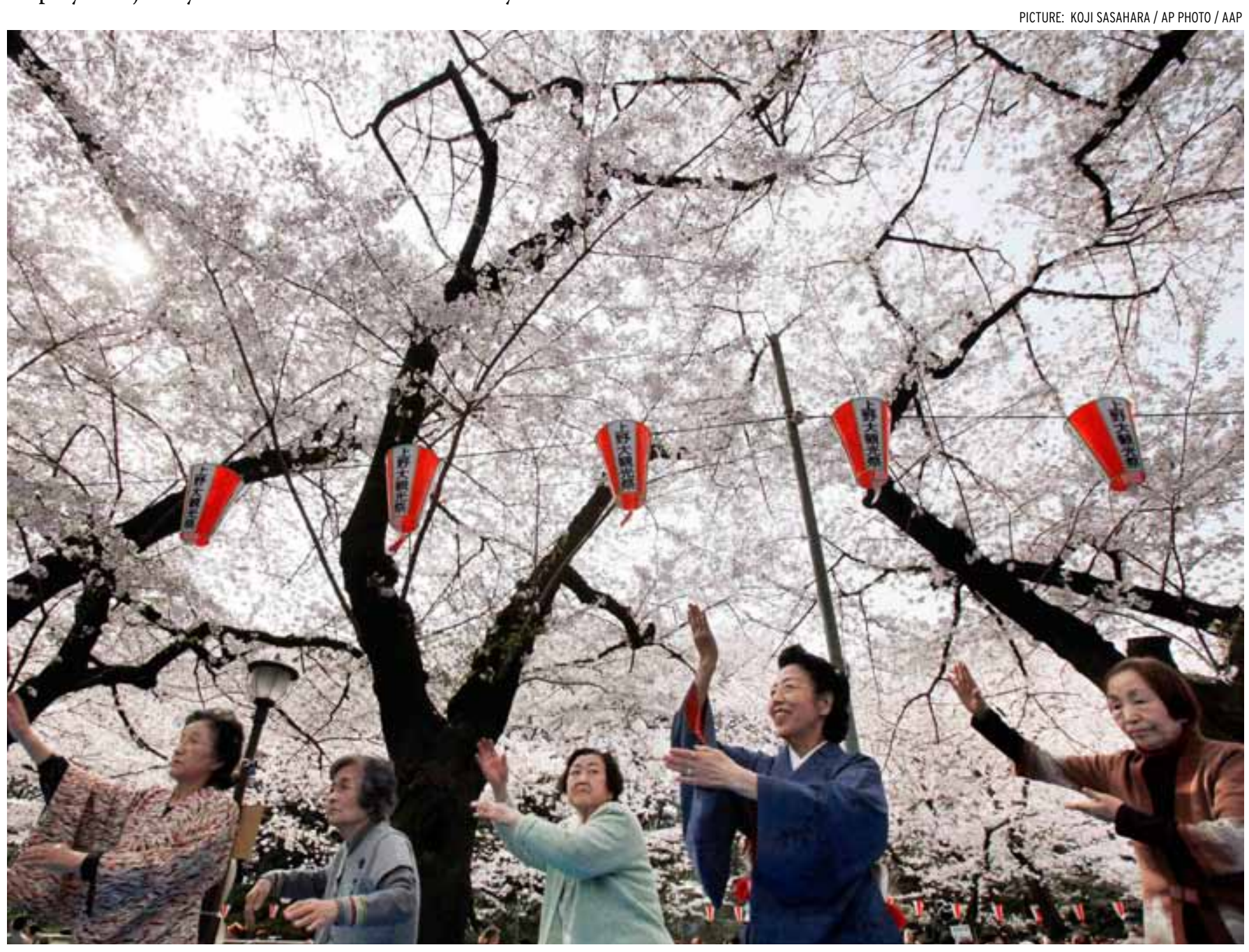

Teacher Miya Edakawa, second from right, leads a group of older women in their dance routines at a cherry blossoms viewing party at Tokyo's Ueno Park. Dancing is believed to be beneficial to older people's welfare. Despite high education levels, women's skills have been under-used in Japan's workforce.

10 EAST ASIA FORUM QUARTERLY JANUARY - MARCH 2016 


\section{Change needed for China to continue its steady climb}

YIPING HUANG

W HEN its GDP per capita hit almost US\$7500 in 2014, China entered the middle-income stage of economic development. Relatively few countries that have made middleincome status in the past three or four decades have graduated to highincome status, or achieved per capita incomes over US\$16,000.

Now the Chinese economic slowdown has raised questions about whether China will be able to continue its steady economic growth to avoid this middle income trap in the coming decade.

Whether China makes the transition to high-income status is probably one of the most important economic questions facing the world today. Success can lift the living standards of 1.4 billion people. Failure may lead to economic and social instability in China and the world could lose one-third of its global economic growth engine.

Economists are divided on the subject. While some predict that China will join the high-income club by around 2020, others argue that the prevailing pattern of regression to the mean in cross-country growth rates should create substantial doubt about extrapolative forecasts of China's growth, and anticipate that there is a significant risk of a major growth slowdown in the next decade.

There are currently two economic cycles leading to slower growth in China's economy. The first is a typical

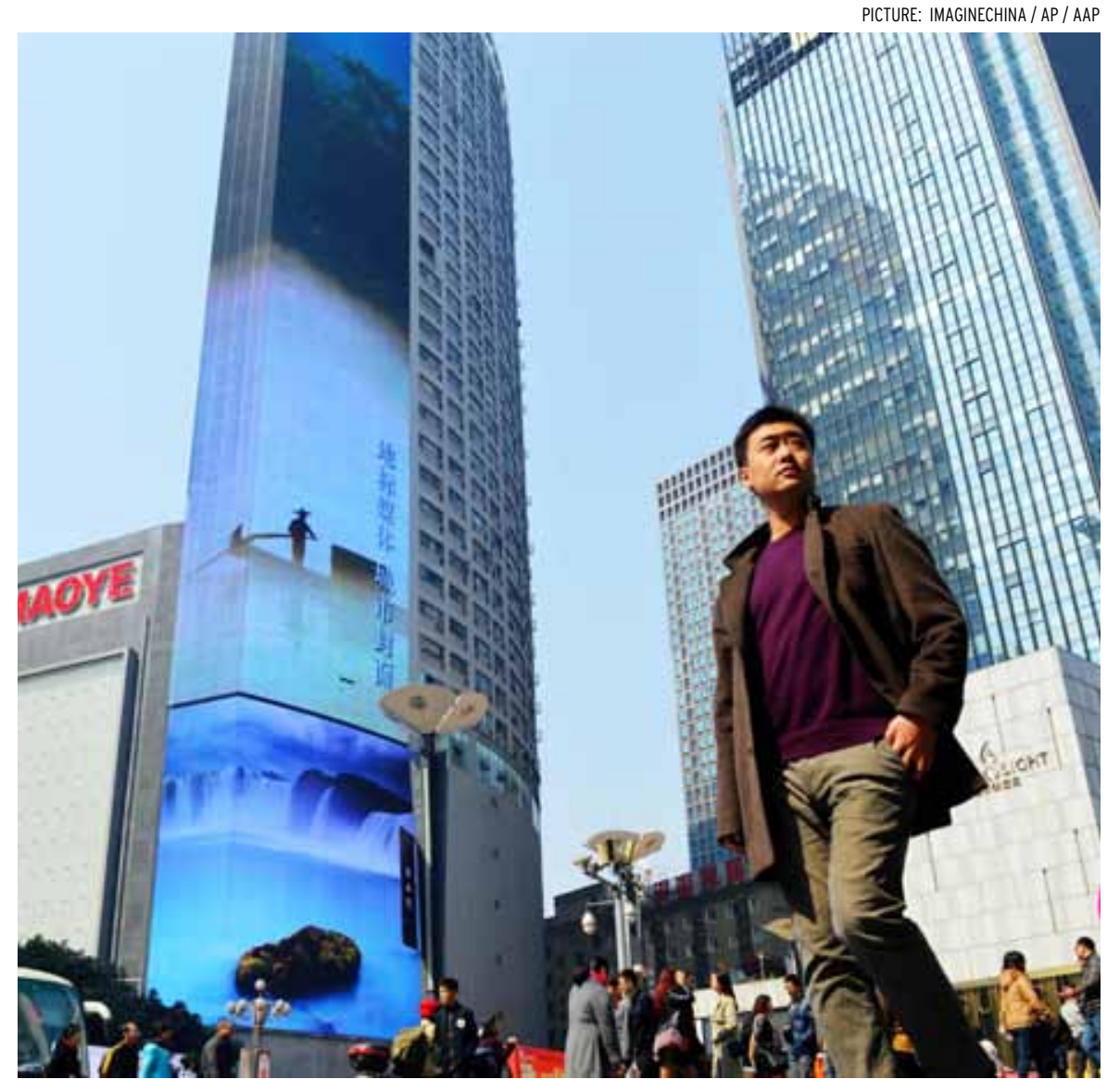

A thriving business district in Chongqing, a city which has already begun to move from basic manufacturing to high-value-added industries. Although new industries are forming, however, it may be some years before China moves away from labour-intensive manufacturing.

shorter-term macroeconomic cycle. The longer-term structural transition is likely to continue to push trend growth lower until new leading industries are well established to take the economy to the next level.

Some new industries are already forming, such as online shopping, express delivery, large machinery equipment and heavy trucks. But these are not yet ready to replace leading industries of the past, particularly in the labour-intensive manufacturing export sector and the heavy industry investment goods producers. And it will take more than a couple of years before they can begin to do so.

More worrying than the growth slowdown is weakening productivity, which underlines the unsustainability of China's current model. Continuing strong economic growth requires a transformation of the current growth model. Often characterised by strong 
growth with serious structural imbalances, the current model has its root in China's transition strategy, with its two dual-track approaches. The first dual-track is between state-owned enterprises (SOEs) and non-SOEs, while the second is between product and factor markets. The continuous protection of SOEs ensured social and economic stability during the early stage of reform but also had negative social, financial and fiscal consequences.

The need for SOE protection also gave rise to the second dual-track approach: factor market distortions. While depressing input costs, these distortions-including financial repression and energy price settingare akin to subsidies to producers, investors and exporters but taxes on households. They explain why economic growth may been extraordinarily rapid but was also associated with growing structural imbalances, including the continuous rise in the GDP shares of exports and of investment, a falling consumption share, income inequality and waste of resources. Transforming the growth model requires completing the transition to a market economy and abandoning factor market distortions. And this in turn requires successful reform of the SOEs.

The good news is that China's growth model is already changing, as

\section{EASTASIAFORUM}

IN OUR NEXT ISSUE ...

\section{GENDER AND SEXUALITY}

While China is unlikely

to move to a

Western-style democracy

any time soon, certain

political changes are

necessary to ensure the

free flow of information,

to maintain order and to

resolve social conflict.

shown by a narrowing current account surplus, rising shares of consumption and services in the economy and an improving income distribution. But so far this has been mainly triggered by changes in the labour market as China reaches the so-called Lewis turning point, from a surplus to shortage of labour. The liberalisation of financial markets, the land market and energy policy are now critical for this transformation to continue.

The real challenge of the middle income trap is an economy's ability to develop new competitive industries and companies after reaching the middle-income level. Countries that fail to do that would be stuck in the middle-income range, unable to compete with either more advanced economies (because of lower efficiency) or less developed economies (because of higher costs).

Although most of China's industries have been built on low-cost products produced with foreign technology, compared with most countries at similar stage of development, China's innovation and upgrading capability is already quite high. Its share of research and development in GDP already exceeded 1 per cent-a benchmark at which most economies' innovation takes off-at a much lower income level than the average of the developing world. China is already one of the leading owners of patents globally, although most of the patents are at the lower end of the technological ladder.

But China still needs to make huge efforts to foster its innovation capability. It must strengthen its research and education base, including training for more than 300 million migrant workers. China also needs to reform its financial system, including liberalising the interest rate and developing new channels of financial intermediation in order to provide better financial services to innovation activities. And it must construct new legal and political institutions that are conducive to technological innovation. This includes protection of intellectual property rights and liberalisation of entry in many sectors.

While China is unlikely to move to a Western-style democracy any time soon, certain political changes are necessary to ensure the free flow of information, to maintain order and to resolve social conflict.

With these reforms, China can hope to rise to high-income status and continue on its path to becoming the largest economy in the world. But there are some very high hurdles to negotiate on the way. EAFQ

Yiping Huang is a Professor of Economics at the National School of Development, Peking University, and the editor of the China Economic Journal. 


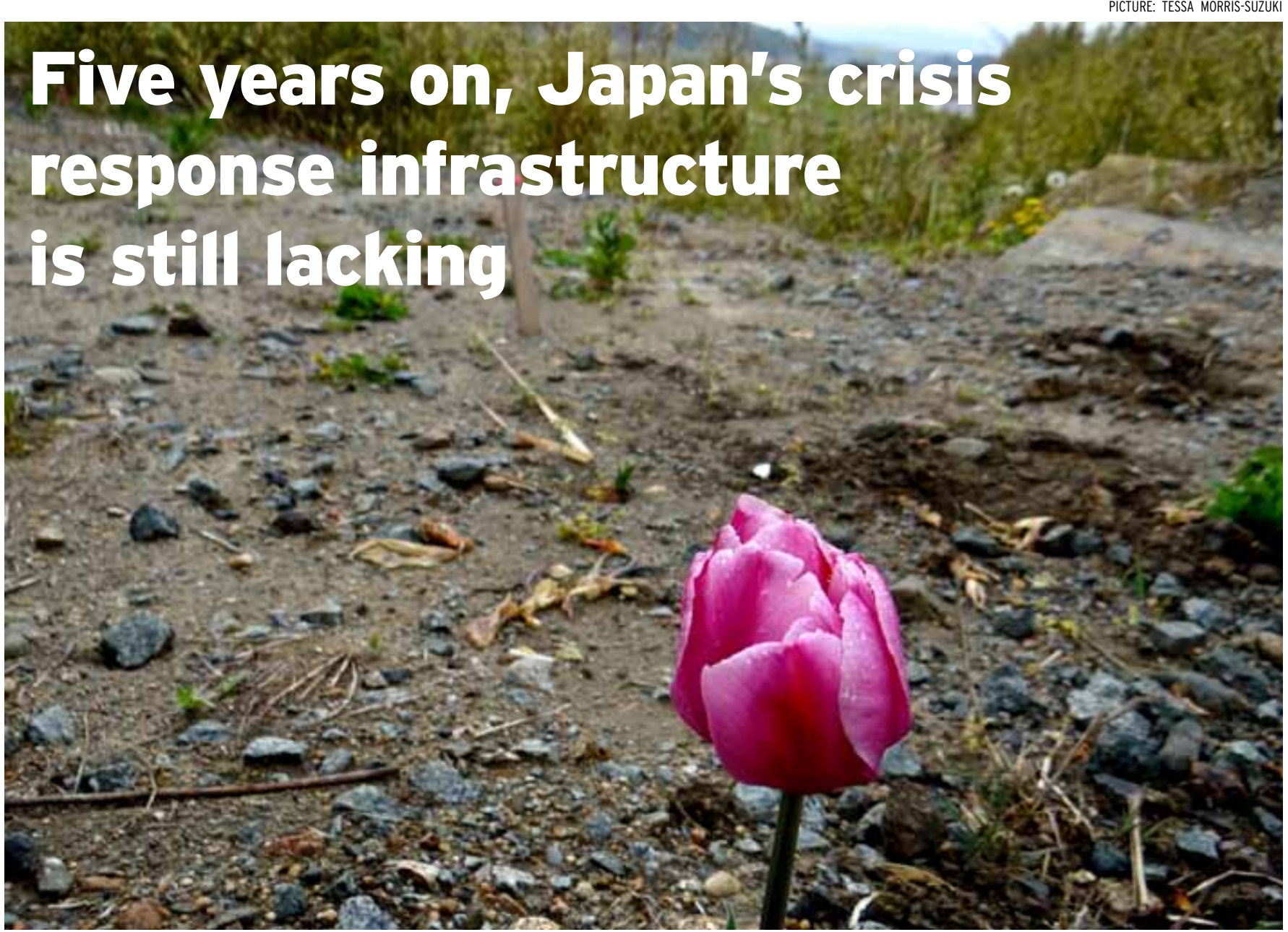

KAY KITAZAWA

N THE face of the 2011 triple

disaster, the residents of

Fukushima banded together to manage the crisis. The word kizuna has become widely used to describe the people-to-people bonds underpinning the remarkable endurance displayed by the residents of Fukushima. Kizuna refers to the strength of Japanese society. It signifies the ties that bind people together and thus Japan's intangible social resources.

Journalists and academics have honed in on how kizuna affects the recovery process in the aftermath of disasters, highlighting the critical role of social networks and personal contacts in forming the core engine of recovery. Undeniably, kizuna served as the foundation of resilience and the recovery in Fukushima. But it is an unfortunate reality that in 2011 Japan had to resort to kizuna, even during the initial phase of crisis management, due to inadequate centralised management.

The Rebuild Japan Initiative Foundation studied the responses of four hospitals located within a 20 kilometre to 30 kilometre radius of the Fukushima Daiichi Plant immediately after the 11 March disaster. This area was designated as a sheltering zone, within which people were allowed to stay but were required to remain indoors whenever a radioactive plume was expected to pass by. A number of commercial companies-including
A flower grows in wasteland left by the tsunami of 11 March 2011 near Minami Soma.

couriers, medical suppliers and agencies that supply support staff to hospitals-opted to cease providing services and withdrew their staff as early as the evening of the disaster.

Within two days hospital staff had fallen by two-thirds on average and stockpiles of medicine and other essentials had begun to run out. With supply channels skewed and minimal personnel, four hospitals were left to their own devices. All became seriously under-resourced and resorted to frantically calling any of their available contacts for help.

The study revealed the challenges each hospital faced, both in the 


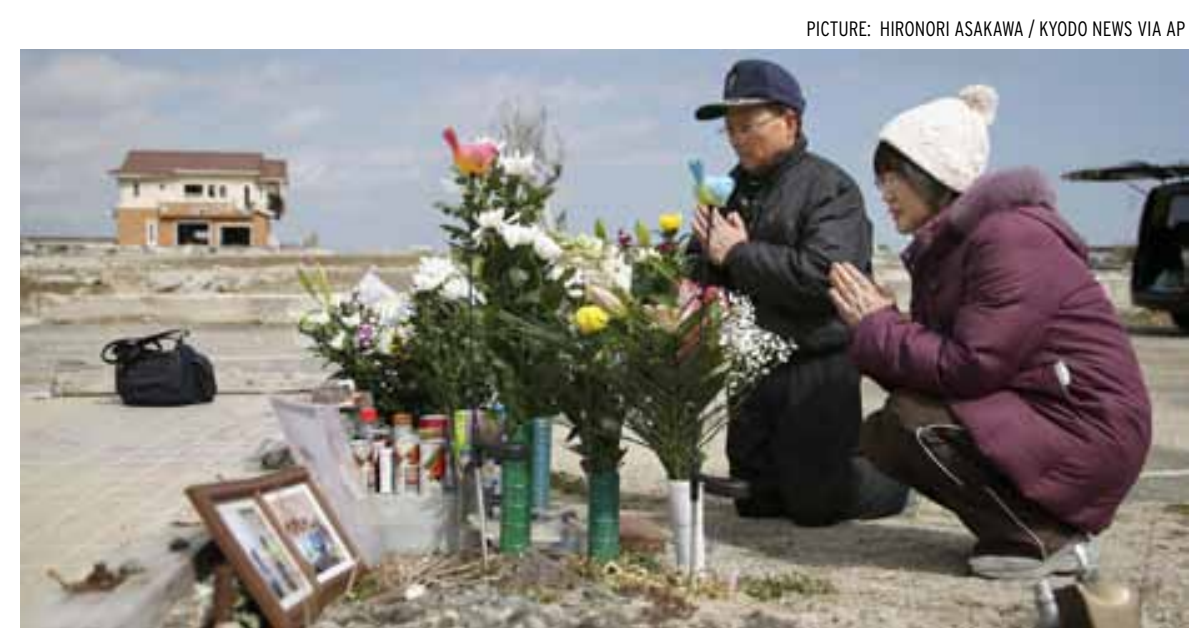

A couple offer prayers for the dead at a commemoration in Namie, Fukushima province.

logistics required to maintain medical functions and in making the necessary preparations for voluntary evacuation. Under the current disaster management system, Fukushima prefecture's disaster control headquarters was supposed to gather all relevant information from the representatives of each division responsible for a specific issue, such as provision and transportation of necessities. But, with a shortage of staff and insufficient information, the malfunctioning of the headquarters was inevitable.

Rarely was a hospital able to reach the headquarters, thanks to substandard telecommunications, and even when it was possible hospitals found the headquarters overstretched and overwhelmed. This prevented the efficient matching of available resources to needs, and inhibited authorities from facilitating the delivery of much-needed medical goods, food, water, gasoline and other forms of help to hospitals for a week, before an official supply route was set up.

Instead, what filled this gap in centralised management in the first week after the disaster was spontaneous operational coordination arranged through personal connections. Some of the four hospitals managed to continue providing community healthcare and medical treatment to critical patients until they finally transferred them outside the sheltering zone. This was made possible by the voluntary support of a few companies that decided to continue deliveries to the area, namely Kowa Yakuhin, a major Fukushima-based pharmaceutical supplier, and Koike Medical, a provider of medical gases, and the efforts of the Japan Self-Defense Forces (SDF).

Moving supplies to, and evacuating patients from, these stranded hospitals relied entirely on the SDF, since virtually no one else dared to enter the sheltering zone until the beginning of April. The SDF took over transportation during the last 10-kilometre leg, although this was not in their original mandate. Hospitals and the SDF orchestrated their operations through the personal connections doctors formed through various channels such as their university alumni communities, through individual politicians at both the local and national level, and through the national academic network that extends beyond Fukushima.

Despite their brave efforts, there is a major drawback to this type of bottom-up, network-based crisis response: it puts too much reliance on the capabilities, attributes and connections of each individual. The director of one hospital-who had social resources outside of the local health authority's official jurisdictionmanaged to ensure relatively smooth coordination between large hospitals in other prefectures, the SDF, local police and municipalities. Not all hospitals were so fortunate. Those with lesser social resources could not hold out longer than few days and therefore decided to temporarily suspend operations, moving out of the area. After only 10 days, with all four hospitals voluntary evacuated, healthcare in the sheltering zone ceased.

It was only possible to continue healthcare services during those 10 days through the herculean efforts made by the volunteers who remained. A crisis response framework based on such self-sacrifice is fragile and cannot be applied elsewhere. Japan urgently needs to examine the logistical and evacuation problems that undermined its disaster management system. But five years on, little progress has been made.

Instead of one-off and ad-hoc support arrangements, Japan should install systematic public-private coordination schemes that clarify the systems for medical collaboration and a compensation scheme for the collaborators not only in a crisis, but also during ordinary activity. Japan must now look beyond kizuna and build a crisis response apparatus that doesn't overly rely on the goodwill of the Japanese people. EAFQ

\section{Kay Kitazawa is Research Director at the Rebuild Japan Initiative Foundation.}




\section{Integration can keep the region above US-China fray}

WING THYE WOO

M ANY features of the US-Soviet cold war are present in contemporary US-China relations: ideological competition, struggles over the control of natural resources, and old-fashioned rivalry for leadership of the global community.

The question for ASEAN is: what is the likelihood of a cold war between US and China taking place on Southeast Asian soil? And what is there to be done to prevent a new cold war? Optimists among us would say that both Xi Jinping and Barack Obama are fully cognisant of the tremendous waste such a confrontation would entail. More importantly, neither the Chinese people nor the American people fear or dislike each other enough to support another cold war.

But our species can be shortsighted or short-tempered. The inescapable fact is that there will always be conflicts between nations of varying intensity. A low-level conflict resembles a conflict between siblings. In this situation, China and the US would be able to resolve differences through bilateral diplomatic means, and Southeast Asia would be left to its own devices by default through benevolent neglect.

With US-China tensions at a medium level, ASEAN countries would profit from the separate efforts of both countries to 'win friends and influence people.' This is why China bought a possibly overpriced power station from the now-infamous 1Malaysia Development Berhad, why President Obama played golf with Malaysian Prime Minister Najib as a show of political support, why China made a more generous offer than Japan to build the high speed railway connecting Bandung and Jakarta, and why the US granted extraordinary exemptions to Vietnam

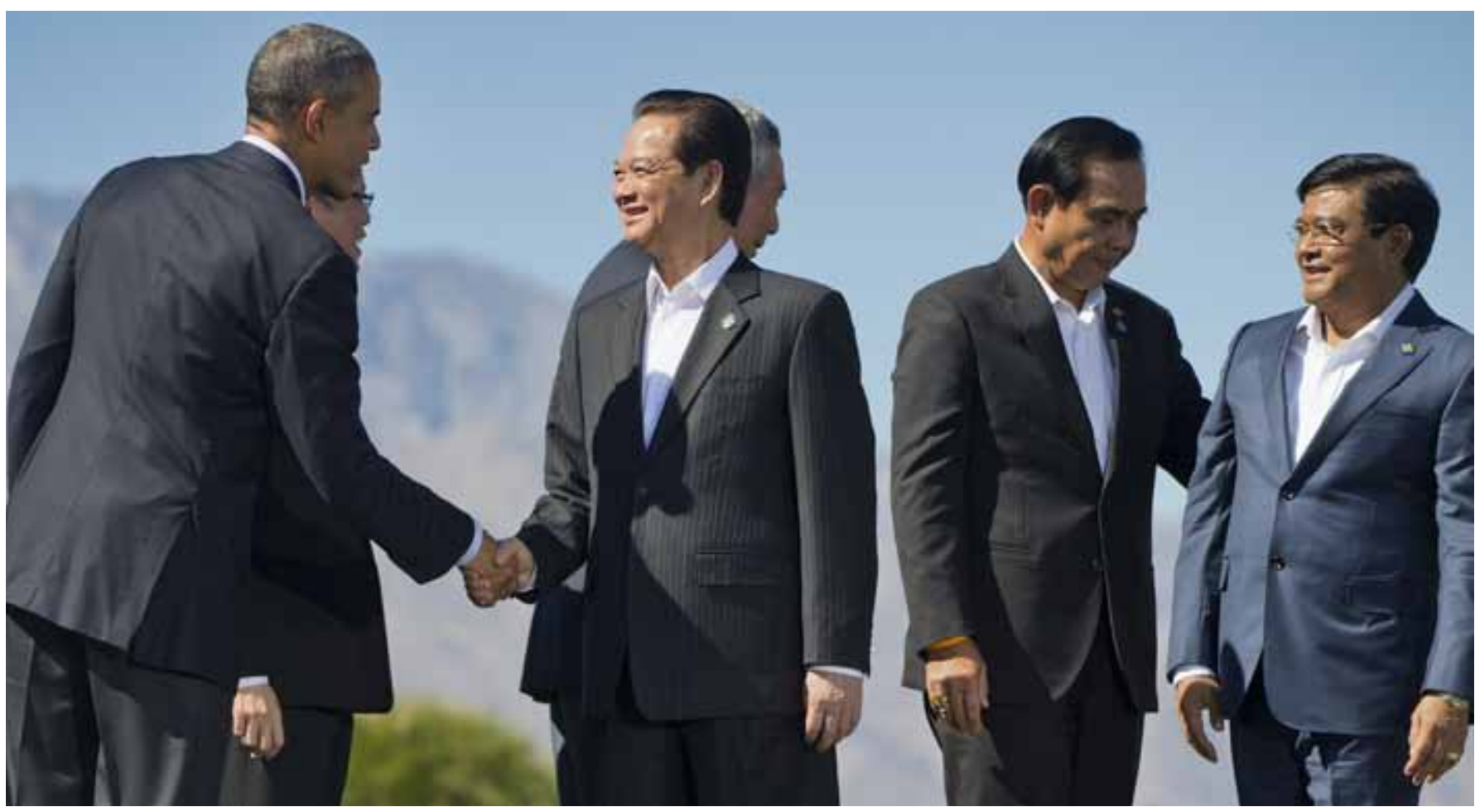

US President Barack Obama greets Vietnamese Prime Minister Nguyen Tan Dung at the meeting with ASEAN leaders at the Annenberg Retreat, Sunnylands, California, in February 2016. ASEAN nations can profit from separate US and Chinese efforts to 'win friends and influence people'. 
and Malaysia in the Trans-Pacific Partnership negotiations. More recently, in February 2016, President Obama hosted a special get-together for ASEAN leaders in Sunnylands, California.

A more high level conflict would see tensions at the height of the US-Soviet cold war. To ASEAN's detriment, both the US and China would adopt the stance of 'if you are not with me, then you are against me', forcing ASEAN to take sides. ASEAN cannot be a bystander in the present intensification of US-China rivalry, and its members must now work together on three fronts.

The first front is to work with other countries and international bodies (like the UN, the EU, the Organisation of Islamic Cooperation, and the African Union) to strengthen existing global mechanisms of conflict mediation such as the ICJ and WTO.

The second front is to establish a strong regional mediation institution located in Southeast Asia itself. The question is whether it could be built without China's support. It is generally to China's advantage to delay the establishment of such a regional institution because China can count quite confidently on being an even bigger economic and political power in the future, and hence would have a bigger influence on the institution founded at that later point in time than if it were to be set up now. ASEAN has to make China realise that this future advantage has to be weighed against the greater risk of driving ASEAN irreversibly closer to the US in the present.

The third front is for ASEAN to quicken its rise as an integrated economic powerhouse. ASEAN has to be important enough to the economic health of both the US and Chinese economies in order for them to acquiesce to ASEAN's requests to strengthen global institutions and to participate in the ASEAN regional mediation mechanism.

ASEAN economic integration will require every member to undertake two sets of reforms. The first is to boost economic development in each country. For example, Malaysia and Thailand, the two most advanced ASEAN countries after Singapore, have been caught in the middle income trap since 1995. The ratios of the standard of living in the two countries to that of the United States have been stagnant since 1994. ASEAN countries must implement important regulatory reforms to terminate the privileged positions of inefficient but politicallyconnected firms, and bring education systems to the level of Japan, Hong Kong, South Korea, and Australia.

$\mathbf{T}$ HE second set of reforms is to accelerate the process of economic integration to achieve the declared objectives of the ASEAN Economic Community (AEC). The AEC must become as integrated economically by 2020 as North American Free Trade Agreement is today. While ASEAN members are embracing tight economic integration with each other through the AEC, they should also embrace economic integration with the United States through the TPP, and with China through the Regional Comprehensive Economic Partnership (RCEP).

Economic integration will result in losers as well as winners. Because the gains of the winners will exceed the losses of the losers, ASEAN must mobilise some of those gains to fund programs to compensate the losers, such as trade adjustment programs to facilitate the transition of displaced workers to new jobs, and, in the case of Malaysia, to subsidise the poor's ability to purchase drugs that would increase in price due to the TPP shutting out some types of generic medicine. The reason why the TPP debate was particularly rancorous in Malaysia, despite the unusually large concessions extended by the US, was the government's failure to extend any meaningful trade adjustment assistance to those hurt by TPP membership.

The above sets of reformsdomestic economic reform, accelerated regional economic integration through the AEC, and policies to soften the social impacts of economic restructuring-must be implemented simultaneously because they are synergistic in nature and their interaction will speed up the emergence of ASEAN as a world economic power. For example, the treaty commitment of an ASEAN member to bring AEC to fruition within a specified time period can be one of the arguments used by its government to defeat interest groups blocking badly-needed economic reforms.

The prudent strategic response by ASEAN to US-China rivalry is to first strengthen global institutions and to establish a regional mediation mechanism to prevent the escalation of US-China tensions; and second, to enact the reforms that are necessary to create an economically powerful ASEAN Economic Community. The best defence is a strong regional economy, and ASEAN should convert the US-China threat into an opportunity for region-wide economic integration. EAFQ

Wing Thye Woo is President of the Jeffrey Cheah Institute on Southeast Asia, and Professor at the University of California, Davis, and Fudan University. 


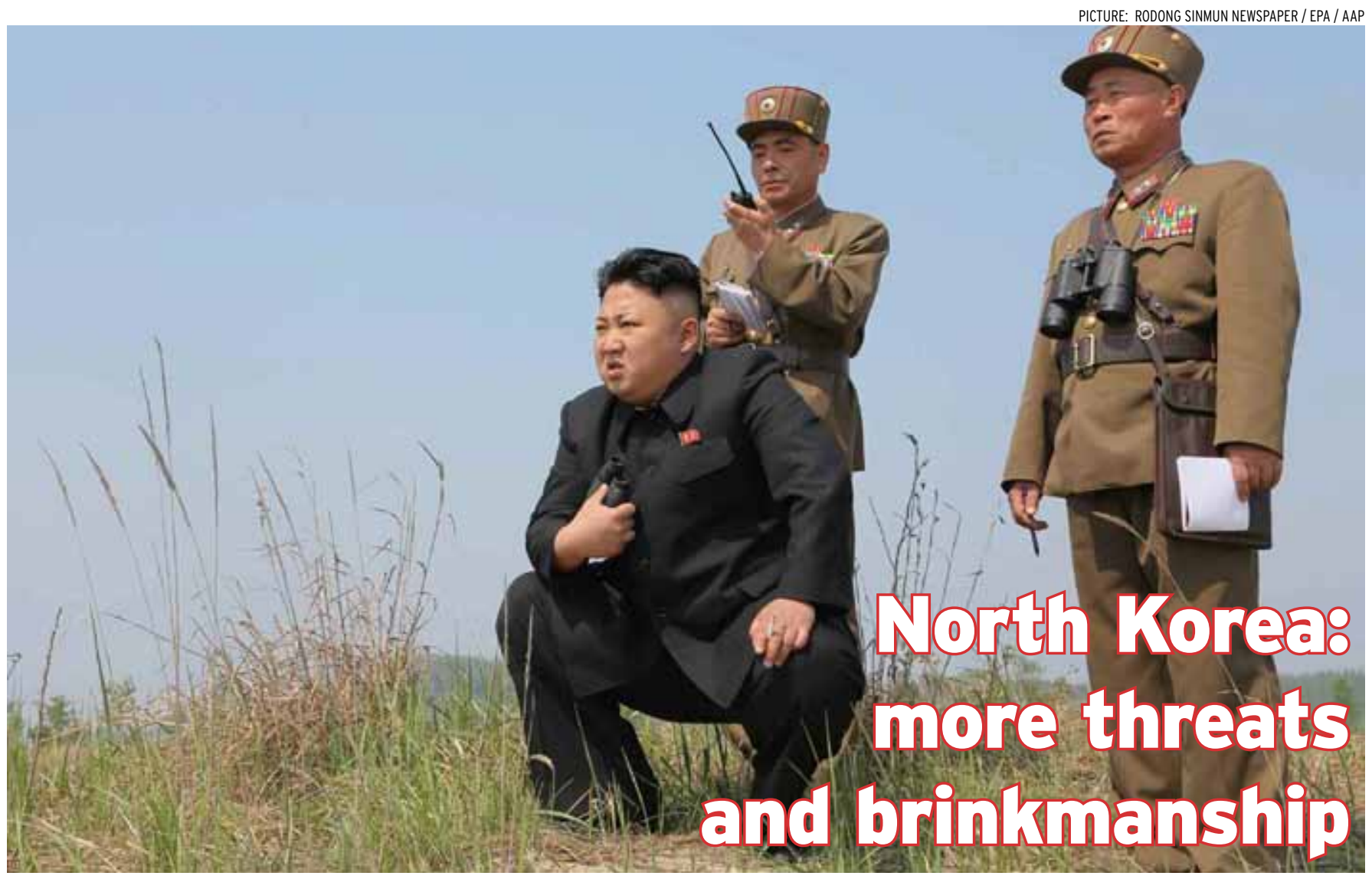

PETER HAYES

AND

ROGER CAVAZOS

$\mathbf{T}$

HE FIRST two months of 2016 showed that North Korea's leader, Kim Jong-un, is committed to creating a new leadership doctrine in order to maintain domestic power. This doctrine is based on economic growth and demonstrated nuclear weapons prowess.

North Korea held its fourth nuclear test on 6 January 2016. It was hailed by the official Korea Central News Agency as a 'smaller H-bomb'. A partially successful satellite launch followed on 7 February, the sixth long-range rocket fired since 1998 and the second to succeed. Though the satellite is not communicating, it temporarily achieved a stable orbit before tumbling - a small step forward from a similar launch in 2013.
The nuclear test and rocket-satellite launch was a direct challenge to the United States and South Korea. This aggressive military testing also forced China to clarify its support for the North Korean regime, even as it denounced both the nuclear test and rocket launch.

These events paved the way for the first congress of the Workers' Party of Korea in three decades and herald major structural changes in the way North Korea operates as a polity and an economy. On 2-3 February North Korea held an unprecedented joint meeting of the Central Committee of the Workers Party and the party's Korea People's Army Committee. More joint meetings and rare 'expanded sessions' are expected in the lead-up to the revived party congress that will take place in May 2016.

They also raise the possibility of political and military collisions with
North Korean leader Kim Jong-un watching a firing drill by a women's artillery unit in January 2016.

South Korea and the US in 2016. Kim Jong-un has demonstrated that he has no intention of capitulating to international demands over nuclear, missile, military and human rights issues.

North Korea's internal resilience and place in the international system mean that its strategic posture cannot easily be changed by external pressure. But a comprehensive regional approach could induce North Korea to 'normalise' its domestic and international behaviour in ways that external pressure failed to achieve in the first four years of Kim Jong-un's rule.

North Korea's suryong or 'Supreme Leader System' faces serious challenges. Unlike his predecessors, Kim Jong-un cannot simply impose 
his will on the party and the military. He cannot bend the economy to support his leadership and that of the military without allowing a powerful market dynamic to emerge. He cannot suppress a new class of those made wealthy by black and informal markets, including high-ranking officials forced to enter into markets due to persistent state poverty. And since around two million people now use cell phones, he cannot ignore a population increasingly exposed to external information.

Kim is riding a tiger, one that originated under his father and grandfather's rule. Whether he can remake the rigid party-military system to sustain his personal control is an open question. But his actions in the opening months of 2016 suggest he will not shrink from this task. Should he succeed-and long-term North Korea observers predict that he willthen North Korea will emerge in the coming decades as a powerful spoiler state.

A RMED with nuclear weapons, North Korea will be able to veto efforts to integrate the region in search of solutions to shared problems. Nuclear weapons experts suggest that North Korea's tests in January may have involved a fusion-boosted fission detonation. A boosted fission device is useful for developing a long-range nuclear force that could enable North Korea to miniaturise a warhead that could be put atop a long-range missile which the US would perceive as a direct, existential threat.

However, North Korea still lacks a well-tested long-range missile capacity that includes re-entry vehicles and related targeting and telemetry. All these tests have demonstrated is that North Korea can blow up a nuclear weapon in Korea, either in its own
... the main fallout from

the nuclear test and the

rocket launch has been

the pall cast on

inter-Korean affairs

territory during a war, or against South Korea under carefully controlled conditions. Still, these tests create an aura of power around Kim Jong-un that fuels his domestic legitimacy and amplifies the perceived threat to North Korea's external adversaries and even its 'friends' such as China.

Just as important as the nuclear and rocket tests was Kim's address on 1 January 2016. Unlike his rather defensive and introspective New Year's speech in 2015, this year's text brimmed with confidence. While the word 'nuclear' appeared only twice in a 4700 word English translation, Kim's references to 'youth power' were an entirely new and noteworthy theme.

'What makes us look back upon last year with greater delight', Kim declared, 'is that our young vanguard, who are reliably carrying forward the lineage of the Juche [self-reliance] revolution and faith, demonstrated the might of the youth power without parallel in the world by means of their loyalty to the Party and heroic struggle.'

Of course, Kim also noted the importance of the Korean Workers' Party and its role in directing the military. But he returned quickly to his appeal to the youth, noting that, 'Our Party pins a great hope on the role of young people in today's general advance'. Kim's words had been long in the making and have already been translated into concrete terms in a newly opened Youth Museum. It seems that a new doctrine in Kim Jong-un's personal ideological brand is in the making.

Kim started the new year with military tests to underscore the rise of a new generation of leadership. This suggests that he will be much more active in 2016 . He will likely devote much attention and national resources to demonstrating to the great powers and South Korea-but above all to North Koreans-that his personal leadership style is working, albeit slowly and unevenly. This means that he will emphasize the efficacy of his signature byungjin policy, which promotes the parallel development of the economy and nuclear weapons.

A FOURTH nuclear test without concurrent progress on intermediate and long-range delivery systems made little difference, militarily speaking, to North Korea's deteriorating strategic position. But it made a huge difference to a hypernationalist appeal aimed at lending Kim Jong-un celebrity status and legitimacy among the youth of North and South Korea.

Relatively little attention has been paid to the domestic and political dimensions of Kim's strategy for regime survival and prosperity, not least because of popular theories predicting the imminent demise of the North Korean regime. But Kim is not crazy, erratic, nor at the end of his strategic tether. Far from a last gasp, the 6 January 2016 nuclear test was merely the punctuation point at the end of his 1 January speech, and the opening salvo in a generational transition in North Korea.

Nuclear testing reinforces Kim Jong-un's reputation as a hardliner 
as he prepares for the resumption of the Party congress after a 30-year break. The fourth nuclear test can be viewed as a present of national fealty delivered to Kim by the North Korean scientific and technical elite two days before his 33rd birthday. This carefully choreographed sequence of events underscores the potency of the current leadership in contributing to, and even surpassing, the achievements of Kim Jong-un's father, Kim Jong-il, and grandfather, Kim Il-sung. Kim Jongun's legitimacy was reinforced by the 7 February rocket launch, putting him in a strong position to direct changes at the forthcoming Party congress. There, Kim will likely set out to re-order North Korea's rigid bureaucracies and ailing state-based economy, since only the hardest hardliner can create domestic wherewithal to re-order and possibly effectuate even the most minor of reforms.

The international community failed to respond to the nuclear test in a timely and coherent manner. The predictable condemnation from the US and its allies did nothing to dissuade North Korea from launching its rocket on 7 February. The ill-advised

American response-sending a B52 bomber to fly over Osan air force base on 10 January 2016-simply lent credence to Kim's embrace of nuclear weaponry and the power of the Supreme Leadership system. This flight was a repeat performance of the tactically smart but strategically fruitless flight made during the 2013 confrontation between the two Koreas.

Apart from expanded discord between the US and China, the main fallout from the nuclear test and the rocket launch has been the pall cast on inter-Korean affairs. The US will expand its unilateral sanctions with little effect on North Korea's nuclear program. But South Korea's decision to shut down completely the interKorean Kaesong Industrial Complex led to an immediate reoccupation of the related section of the Demilitarised Zone by the North Korean military. This outcome portends an ugly North Korean riposte and a period of overt and covert military confrontation in 2016.

Decades of incremental attempts to stop and reverse North Korea's breakout have failed completely. The only actions that were at all effective were former president George H. W. Bush's 1991 unilateral withdrawal of nuclear weapons from South Korea, and the 1994 US-DPRK Agreed Framework brokered by the Clinton administration. The former led to a new benchmark for inter-Korean agreements-particularly the 1992 Denuclearization Declarationthat remain a baseline for future denuclearisation of the North. The latter reshaped the strategic landscape in ways that altered Kim Jong-il's calculus enough to slow North Korea's nuclear weapons production by more than a decade.

M ORE international dithering will enable the DPRK to acquire a full-spectrum nuclear deterrent within the next two decades. From Kim Jongun's perspective, only a comprehensive regional security settlement between the great powers, combined with a regional nuclear weapons-free zone, can provide a substitute for North Korea's nuclear weapons. This is not because military threats from the US or others would recede greatly in this scenario. Latent nuclear threats would still remain in the background even if changes are formally made in the regional security framework. Yet Kim's leadership would gain more recognition from such treaty-based agreements than he could ever hope to gain from a renegade nuclear weapons program.

Unless an attempt is made to change Kim's strategic calculus, it is virtually certain that the DPRK will conduct more nuclear tests and launch more satellites. It may even start to test long-range re-entry vehicles and convert space launch rockets into ballistic missile delivery systems.

But it is not inevitable that North Korea will acquire long-range missile capabilities. Because it will lack a militarily meaningful long-range missile system for years to come, the international community still has time to slow down its inexorable march towards a capable nuclear weapons program. Yet it seems unlikely that the international community will engage with the North Korean challenge to the extent that is necessary. The US is unlikely to meaningfully engage with North Korea in the run-up to the US presidential elections, and the USChina relationship is already fraught with other issues in ways that preclude close concert on North Korea.

This external environment leaves Kim Jong-un free to use nuclear tests and irregular missile activity for opportunistic psychological warfare against the South. North Korea will continue to rely on conventional artillery and rockets aimed at Seoul as the foundation of its deterrence strategy against attack by the US and South Korea. Rigid responses to Kim Jong-un's nuclear test do not portend a break in this cycle of threats and brinksmanship in 2016. EAFQ

Peter Hayes is Honorary Professor, Center for International Security

Studies, Sydney University, and Director of the Nautilus Institute in Berkeley, California. Roger Cavazos is a researcher at the Nautilus Institute. 


\section{Australian leaders' conceptions of Asia}

FRANK BONGIORNO

A FEATURE of Australia's

relationship with Asia is that each generation considers itself the first to have fully 'discovered' Asia. Some years ago, in June 2011, the Premier of Western Australia, Colin Barnett, gave a lecture in London. The China boom was in full swing; demand for Australian resources seemed as if it were impervious to ordinary economic cycles. Oddly, Barnett called his lecture 'More than China's Quarry', for his argument demonstrated exactly the opposite: that in economic terms, a Chinese quarry was more or less what Western Australia had become.

All of that now seems a long time ago. The China boom has passed into history and Australians-and West Australians perhaps more than the rest-are left to rethink their relationship with that vast country as its economy pursues an unsteady transition towards service provision, domestic consumption and lower carbon emissions.

Australia, of course, has been faced with a situation at least a little like this before: in the 1970s and 1980s, when the Japanese ardour for Australian iron ore cooled as that country moved away from heavy industry towards electronics and servicesand secured other suppliers, such as Brazil, providing new competition for Australia. Each generation of Australian politicians and business leaders has apparently seen in Asia limitless possibilities. Only later do they find their dreams of an El Dorado confronted with the realities of the economic cycle, changing Asian government priorities and revised material aspirations-none designed to provide Australians with a living.

The end of the Japanese resource boom demanded adaptation; Australia now finds itself again in this kind of territory, and it is certain that Australian politicians will seek to craft a new 'Asia' in the Australian imagination in response to new circumstances. That has, after all, long been the pattern. From Alfred Deakin, Australia's second prime minister, down to the present, Australia has paradoxically seen Asia as at once rooted in unchanging tradition-and frequently a source of threat-yet apparently also available for the projection of Western-including Australian-economic ambitions.

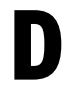

EAKIN'S interests in India are well known. He visited in 1890 to study irrigation, wrote newspaper articles and two books on India, was attracted to its religions and spirituality, and predicted that Australia's future would be much influenced by the subcontinent. According to historian David Walker, he 'looked to India to furnish answers to some of the great questions of his day.' 'No Australian political leader has written more about Asia, publicly and privately', Ipsita Sengupta has declared more recently. Yet Deakin's fascination with, and passion for, India co-existed with support for a 'White Australia'. India might be all that was exotic, but it was also-like the rest of Asia-a threat to the emergent nation.

Any Australian who looked sympathetically on Asia in the first half of the 20th century similarly had to reconcile these sympathies with their determination to defend White Australia. Any other stand on this issue would have been a sure road to political oblivion. Labor Party prime minister Ben Chifley was one of those who did his best to reconcile support for a racially exclusive immigration policy with a liberal internationalism that welcomed the rise of Asia; an awkward, but characteristic, combination for progressive Australian intellectuals. Chifley travelled as a private citizen to the Dutch East Indies between the wars and was deeply touched by its poverty and poor working conditions. It did not dispose him to look favourably on Dutch rule.

Chifley was quite capable of evoking racial fears in his electioneering, but as prime minister (1945-9) he also proclaimed anti-colonialism. Chifley grappled more regularly and conscientiously with the implications of Asian nationalism for Australia than he has been credited with. He greatly admired Jawaharlal Nehru, and directly involved himself in making policy in areas such as Australia's policy towards Indonesian independence and India remaining in the Commonwealth as a republic. In each case, he recognised the force and significance of Asian nationalism.

Largely in response to claims that Asian engagement was a pillar of the Labor Party's foreign policy, the modern Liberal Party has displayed 
an interest in presenting its own side of politics as instrumental in building a new relationship between Australia and Asia after the Second World War. Hence the decision to call the recentlyintroduced scheme of scholarships for Australian students to study in Asia 'The New Colombo Plan', thereby drawing attention to the old one, usually credited to Liberal external affairs minister Percy Spender.

While the Cold War shaped much of Australia's engagement with Asia during the Liberal government of Sir Robert Menzies in the 1950s and 1960s, the Liberal Party can-and occasionally does-point to the 1957 Australia-Japan Agreement on Commerce. Yet it was largely the achievement of the Country Party leader and trade minister, John McEwen, and his permanent secretary, John Crawford, and McEwen seems to have taken from the experience a growing awareness of the significance of Asia for Australia's future. Australia also began selling wheat to the People's Republic of China at around this time.

\section{A} S PRIME minister, Menzies himself showed limited interest in Asia. In contrast with Chifley, he had unhappy relations with Nehru, the most significant Asian leader of the era. And where his external affairs minister, Richard Casey, flirted with the idea of Australia participating in the Bandung Conference of African and Asian Nations in 1955, Menzies was completely hostile to the notion. Menzies also opposed the efforts of his immigration minister, Hubert Opperman, to ever so mildly liberalise the White Australia Policy in the 1960s. Sir Walter Crocker, the academic and diplomat, recorded privately in 1955: 'Menzies is antiAsian; particularly anti-Indian; yes, anti-Asian. He just can't help it'.
It was probably due to the enduring public image of Menzies as an Anglophile hostile to Asia that subsequent Labor prime ministers have been more successful than their Liberal rivals in presenting themselves as Asia-friendly. A succession of Labor prime ministers-Gough Whitlam, Bob Hawke, Paul Keating, Kevin Rudd and Julia Gillard-have sought to deploy Australia's relations with Asia as a means of crafting an image of economic and political modernity. Here was another Asia, one that would have been unrecognisable to Deakin and barely so to Chifley, for whom Asian poverty and related unrest were salient.

For Whitlam, a rhetorical emphasis on closer relations with Asia was a way of distancing his party from the impression, greatly reinforced by Australia's participation in the Vietnam War, that Australia continually aligned itself with 'great and powerful friends' against Asian nationalism and communism. It was also a means of presenting foreign policy as based on cooperation and moral principles more than fear and the calculations of Cold War power politics. Famously, there was Whitlam's 1971 visit as opposition leader to China and his government's subsequent recognition of the People's Republic of China, recognition that coalition governments had staunchly withheld since 1949. It was a mark of Whitlam's achievement that the conservative coalition government of Malcolm Fraser (1975-1983) did not depart drastically from the pattern of relations with Asia that had emerged under Whitlam.

The Hawke (1983-91) and Keating (1991-6) Labor governments continued this trajectory and, as the decade wore on, increasingly emphasised Australia's relations with an economically dynamic Asian region. Hawke's memoirs emphasise the pride he felt in the relations he developed with Chinese leaders, which presumably made the events of June 1989 in Tiananmen Square all the more painful for him. And especially in the wake of the economic crises of the mid-1980s - the collapse in Australia's terms of trade, the balance of payments crisis, the 1986 run on the currency, and Keating's banana republic characterisation of the circumstance of the Australian economy-there was a growing inclination to think about Australia's future in terms of its relations with Asia, and particularly what would be called, in economist Ross Garnaut's influential 1989 report for the government, 'the Northeast Asian Ascendancy'

A USTRALIA played an instrumental role in the formation of Asia Pacific Economic Cooperation (APEC) at this time as a regional organisation concerned particularly with trade and investment. It would be expanded in both scope and membership in the following decade. This was all, in essence, an economic vision, based on the ideal of Australia as a successful and prosperous trader in a regional economy, free of the distortion of tariffs. Accompanying it was the embrace of an immigration policy increasingly geared to this reinvigorated, regionally integrated and internationally competitive economy-and which would inevitably include significant numbers of Asian migrants.

It was Keating's government in particular that tied a 'modern' relationship with Asia to a wideranging sense of Australian national identity: one that was economically 
'open', multicultural, republican and 'reconciled' in its race relations. None of this was predictable in light of Keating's previous cultural interests, which were decidedly Europhile.

But Keating was also a radicalnationalist, and one way of marking off a postcolonial Australian present and republican future from a dependent and imperial past, was to emphasise regional engagement with Asia. This was surely why Keating kissed the ground on the Kokoda Track in Papua New Guinea on Anzac Day in 1992. For Keating, it was here that the nation had defended itself against an invader. And it was also where Australians had been forced to recognise that their own future was irrevocably tied up with Asia, not that of some distant motherland.

When John Howard's coalition defeated Keating at the 1996 election in a landslide, it was widely interpreted that voters had repudiated Keating's vision of Asian engagement, not least because the same election saw the election of Pauline Hanson, a parliamentarian who set herself against Asian migration. Howard's subsequent failure to confront Hanson contributed to the false impression, derived from some ill-judged remarks of his while opposition leader in 1988 over the pace of Asian migration to Australia, that he was himself antiAsian.

But there was initially little change in the overall shape of Australian foreign policy. Australia gained international kudos from its role in the events leading to East Timorese independence in the late 1990s, while inevitably damaging its relationship with Indonesia. But after September 11 , with the emergence of new preoccupations such as the "war on terror' and the forging of new military coalitions to fight it, discourses dependent on the concept of an Anglosphere proved attractive to neoconservatives. In the face of the alleged threat to national sovereignty posed by asylum seekers arriving in boats, and regional terrorist incidents including the Bali bombing, an older notion of defending Australia against Asia regained both credibility and prominence.

It was the spectacular growth of the Chinese economy that would ultimately do more than anything else in this period to reshape how Australian political leaders looked at Asia. By 2009 China had overtaken Japan as Australia's most valuable export market. There was surely a symbolism in Australia electing a Mandarin-speaker in Kevin Rudd as its prime minister in 2007. Educated in Asian Studies at The Australian National University, no prime minister since Deakin had engaged so closely with Asia on a personal and intellectual level. No one, among Australia's political leaders, seemed more capable than Rudd in developing Australia's relations with Asia's most populous and important country.

$\mathbf{Y}$ ET IT was ironically not Rudd who was most critical in driving the Australian relationship with China in this period: it was the senior executives of the mining companies feeding China's apparently endless appetite for iron ore, coal and gas. When Julia Gillard's subsequent Labor government delivered its Australia in the Asian Century White Paper in October 2012, it reflected this sense of growing economic interdependence. It was Asia's economic power-its phenomenal rise as a producer and consumer of goods-which was seen to present Australia with 'a truly transformative period in our history'. The report did not by any means ignore social, educational and cultural links, but these were decidedly secondary to its main purpose of announcing the economic and strategic opportunities and challenges presented by the rise of Asia.

There was no sign in either Gillard or her Liberal Party successor, Tony Abbott, of the driving intellectual curiosity that had motivated Alfred Deakin's interest in India. It may well be, however, that the latest occupant of prime ministerial office, Malcolm Turnbull, revives something of the Deakinite fascination with Asia. Both before and after becoming prime minister, he has delivered thoughtful and well-crafted speeches on China, a country with which he had considerable experience as a businessman. His son speaks Mandarin and has a Chinese-born wife. In some respects, Turnbull's rhetoric harks back to Keating; the relationship with Asia, and especially with a rapidly-transforming Chinese economy, is presented as integral to his government's ambitions for a new, more innovative and more dynamic Australian economy integrated with its region.

All the same, Western Australian Premier Colin Barnett's narrower vision of relations with Asia might still be more typical of official Australia's attitude. As in the past, the temptation is to try to bend Asia to the economic and political purposes of the present. The 'Asias' we encounter in the discourse of Australian political leaders perhaps still tell us more about Australia than they do about Asia itself. EAFQ

Frank Bongiorno is Associate Professor in History at The Australian National University's College of Arts and Social Sciences. 


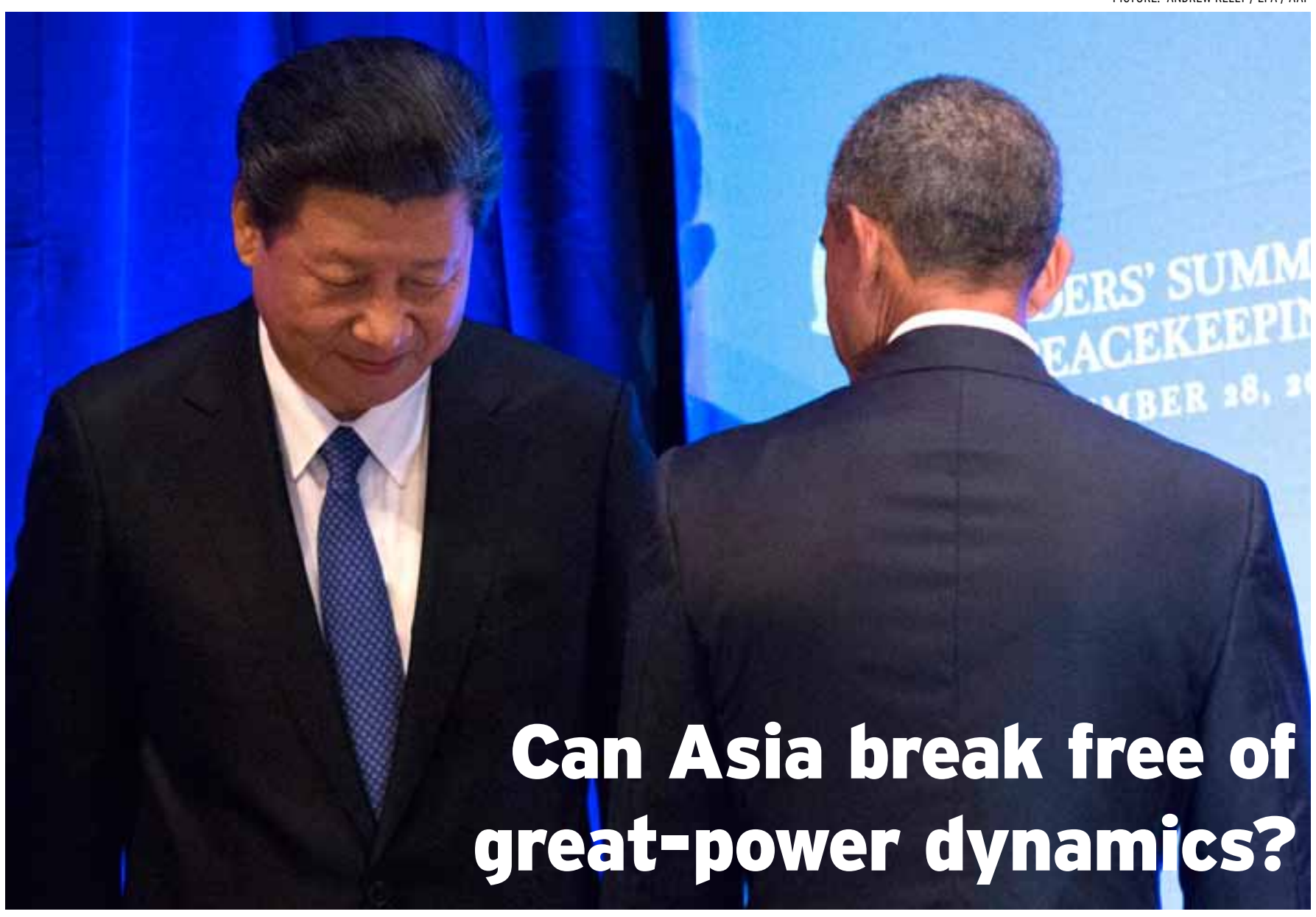

\section{HUGH WHITE}

A SIA'S recent decades of economic growth have depended, among other things, on a remarkable period of regional peace and stability. The region will only keep growing if that can be sustained. We cannot take this for granted. The peace we have known has resulted from an unusual situation that emerged in the early 1970 s, when China decided to follow Japan in accepting the United States as the primary strategic power in Asia. That has meant that US primacy has been uncontested by any major regional power in Asia, eliminating major-power rivalry as a source of tension and conflict.

But US primacy in Asia is now contested again. China no longer accepts American leadership as the foundation of the regional strategic order and instead seeks a 'new model of great power relations. This probably means it wants to take America's place as Asia's primary power, and its new strategic weight means we have to take this seriously. Few, if any, in Asia want China to get what it wants. US leadership has served the region well and no one wants to live under China's shadow.

But wishes are no substitute for good policy. We delude ourselves if we imagine that Asia could be transformed economically by the biggest shift in the distribution of wealth in history without also being transformed politically and strategically. It would have been truly remarkable if China had not sought a
Conflicting assumptions: Chinese President Xi Jinping and US President Barack Obama at the Leaders' Summit on Peacekeeping during the UN General Assembly in September 2015.

bigger regional role as its power has grown, as every rising power in history has done before it.

So rather than just wishing that the old order might last forever, Asia's leaders have to start thinking about how the inevitable transformation of the regional order can be managed peacefully. Throughout the transformation, regional leaders should strive to preserve as many of the positive features of the old order as possible.

So far they have failed to do that. The problem starts in Washington, 
where US policymakers and analysts have remained in denial about the seriousness of China's challenge. They underestimate China's power and resolve, which leads them to think that low-cost low-risk gestures, like those promoted under President Obama's 'pivot', can persuade Beijing to back off. Policymakers still assume that China would not risk the economic costs or military risks of a confrontation with the United States, despite mounting evidence to the contrary. Recent events in the South China Sea, for example, suggest that Washington is more risk-averse than Beijing.

And this year's strange presidential primaries suggest that America's resolve is unlikely to stiffen after November. Donald Trump's mindless braggadocio is as sure a sign of the American electorate's dwindling commitment to sustain the costs of global leadership as Bernie Sanders' refusal even to discuss foreign policy.

All this is compounded by what seems like excessive confidence on the other side of the Pacific. For Beijing it has become too easy to reach an assumption opposite to Washington's-that it will be the US that backs off in the face of modest Chinese pressure and not the other way round. China's actions over maritime disputes in the Spratly Islands and elsewhere seem plainly intended to do just this. They are creating situations that test America's willingness to risk a military confrontation with China on behalf of its allies. Beijing hopes and expects that the US will fail-and so far they have been proved mostly right.

This creates a very dangerous situation. Of course, neither side wants confrontation, let alone war. But each side expects to be able to achieve its aims without confrontation because it assumes the other will back down.

\section{Neither side wants}

\section{confrontation, let alone}

war. But each side

expects to be able to

achieve its aims without

\section{confrontation because}

\section{it assumes the other will}

\section{back down}

And we should be under no illusion about the weight of the stakes for both countries. The maritime issues in dispute are not the cause of USChina rivalry any more than the status of Serbs in the Austro-Hungarian Empire was the cause of the First World War.

Their contest is driven by mutually incompatible visions of the future Asian order and their roles in it. For both of them, this goes to central questions of national identity and destiny. These are just the kinds of issues that great powers do go to war over, and the mutual underestimation of each other's resolve is how such wars start when neither wants nor expects them to.

The risks may well grow in future if Beijing becomes impatient with Taiwan's new government. Tensions across the Strait, which eased under President Ma, would then start to rise again, adding another, even more emotive focus for US-China rivalry.

None of this is to say that confrontation or conflict is inevitable. But it is to say that the risks are very real and the trends are negative. Turning those trends around by finding a way to deescalate the rivalry is essential for setting the conditions for peace, stability and growth in Asia over coming decades.

None of us can afford to leave this to Washington and Beijing, because we simply cannot assume they will get it right. Others with an interest in Asia's future-and that means not just Asians but everyone else as wellought to ask what influence can be brought to bear to help manage the transition now underway in Asia much better than it has been so far.

That means recognising and acknowledging the existence and scale of the risks of escalating rivalry-to break through the complacency that envelopes both Washington and Beijing. It requires us to accept that the old order in Asia is no longer sustainable: we will have a new regional order whether we like it or not. We must therefore think more creatively about what that order might look like. It is too easy to assume that the only alternative to US primacy in Asia is Chinese primacy, and both Washington and Beijing have reasons of their own to encourage that assumption.

But of course there are many other possible foundations for a new Asian order, which would serve the interests of all of us, including the US and China, much better than either a protracted struggle for regional primacy between the world's two strongest states or a passive acceptance of Chinese hegemony. Our challenge is to explore these alternatives and how they might best be brought about. It is an extraordinarily difficult task, but the stakes could not be higher. EAFQ

Hugh White is Professor of Strategic Studies at the Strategic and Defence Studies Centre at The Australian National University. 
PICTURE: IMAGINECHINA / AP / AAP

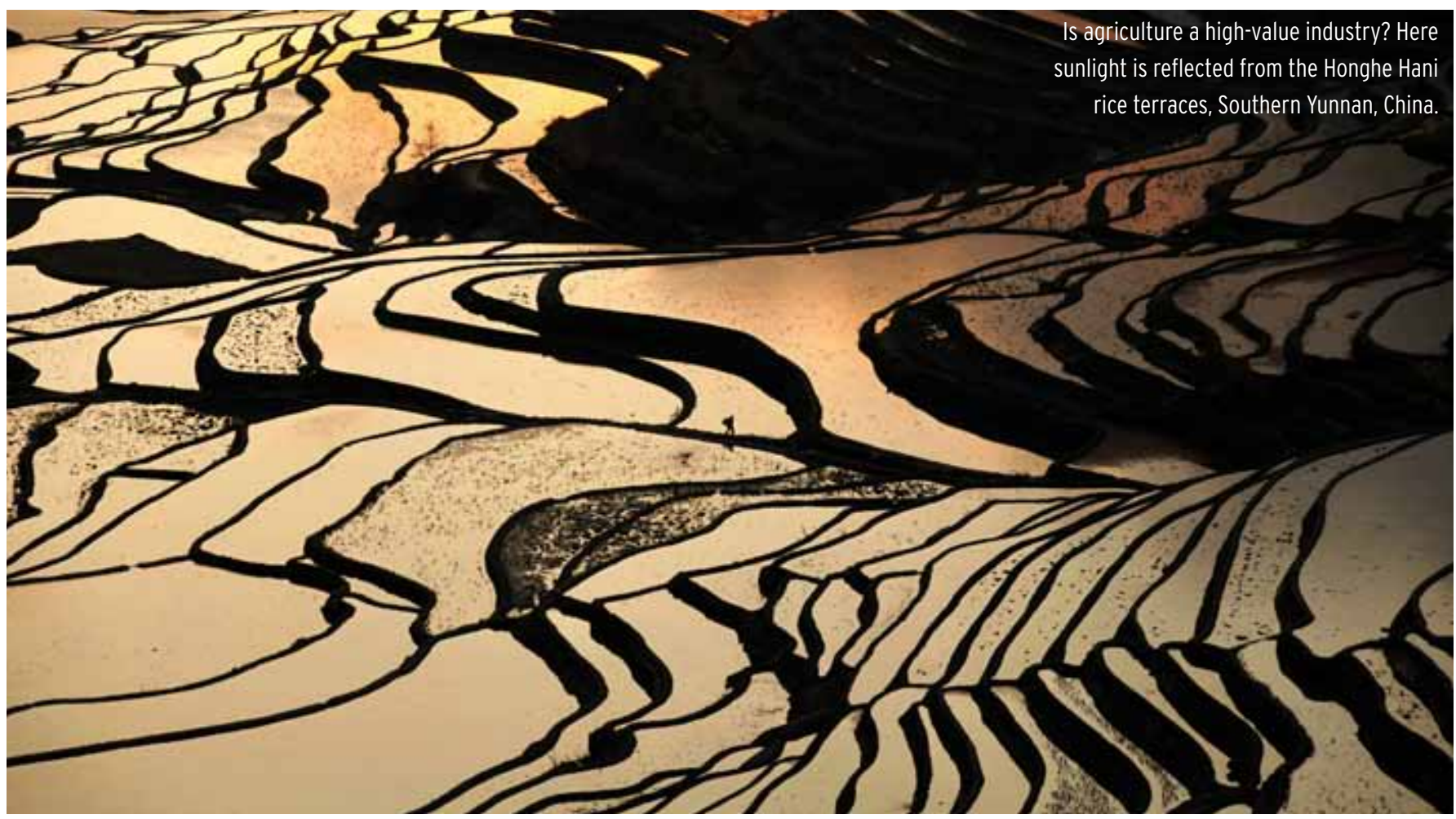

\section{Growth engines and development traps}

JAMES RIEDEL

AND

PHAM THI THU TRA

$\mathbf{T}$ HERE is nothing more compelling than a catchy metaphor to attract attention and garner support for policy prescriptions. 'Engines' and 'traps' are two of the most popular metaphors in the development literature. Both have been used repeatedly to advance various policy agendas in East Asia. But do these metaphors provide a reliable basis for growth policy?

In 1948 Ragnar Nurkse used the metaphor of trade as the engine of growth in the 19th century as a rationale for an import-substitution industrialisation strategy. His argument was that, in the 20th century, trade could no longer be the engine of growth for developing countries that it had been during the preceding century, because of the declining demand for exports from low-income countries. In 1970 Irving Kravis demolished this argument, demonstrating empirically that trade had not been the engine of 19th-century growth-only the handmaiden - and that prospects for export growth after World War II were even greater than in the previous century. This indeed turned out to be the case.

Three decades after Nurkse, W. Arthur Lewis used the same rhetorical device in his Nobel lecture to make a similar argument-namely that while trade had been the engine of growth in developing countries in the first 25 years after World War II, it could not continue to play that role due to a decline in income growth and demand in developed countries. The year 1980 turned out to be inauspicious for Lewis's thesis. It marked an economic watershed in China, after which the country went on to unprecedented double-digit growth following an export-oriented industrialisation strategy.

The metaphor of trade as an engine of growth lives on-China's growth and prosperity are routinely attributed to exports, presumably because 
export-oriented manufacturing was the most dynamic sector of its economy. But this facile analysis begs the question of what was the driving force behind China's export growth. Was it world demand or growth in China's capacity to supply world markets?

It could hardly have been the former, since world demand (for which world income growth is a reasonable proxy) grew at a rate of less than one-fourth of that of China's exports. Instead China's export growth has been driven by growth in China's capacity to supply exports. This capacity growth was driven by one thing: investment. Increased investment resulted not only in capital deepening, but also in technological change (via technology catch-up) and employment growth. No investment, no long-term growth.

The popular mantra in recent years is that China needs a 'new growth model.' China, the argument goes, must transition from investment-led growth to consumption-led growth. But how does consumption - that is, demand-bring about increases in production capacity? At best it can only increase capacity utilisation and thereby increase growth in the short run. In the long run, production capacity can only be increased by capital accumulation and productivityenhancing technological change-both of which are products of investment.

The impact of investment on growth does, of course, depend on how well product and factor markets function and how well the government fulfils its role as a provider of public goods. These in turn depend on policy choices and, more broadly, on political and economic institutions, the main concern of another popular metaphor, the 'middle income trap'.

For past 10 years the idea of a middle income trap has come to dominate policy discussions, especially those about East Asia. The World Bank has pronounced that almost every middle-income country-and some countries that are barely in the middleincome range, including Vietnam and India-are all caught in a middle income trap.

The middle income trap and trade engine hypotheses basically amount to much the same thing. The trade engine hypothesis asserts that trade is the engine of growth, but the engine doesn't work. The middle income trap hypothesis says that countries that follow comparative advantage by adopting the export-oriented industrialisation strategy are headed for a dead end, where the level of a country's prosperity is limited to the productivity of unskilled workers in labour-intensive export-oriented manufacturing.

$\mathbf{S}$ O HOW can countries escape the middle income trap? The solution universally prescribed is to change policy. What is needed, it is often argued, are policies that promote the production and export of 'highvalue products', raise the 'domestic value-added content of exports' and transition to a 'knowledge-based economy'.

This raises the question: what is a 'high-value' product? Are automobiles a higher-value product than fish? The obvious answer might seem to be yes, but if priced by weight both are valued at about US $\$ 5$ per kilogram. The domestic value-added share of primary exports is also close to 100 per cent, while in manufacturing-thanks to global supply chains-it amounts to about 50 per cent in many countries, and in some cases is even lower. Does this mean countries should abandon industry in favour of agriculture?
Transitioning to a 'knowledge-based economy', which presumably means an economy in which the share of income earned from human capital is high and rising, is a worthy goal. Unfortunately, many of the countries that talk loudest about the need to transition to a knowledge-based economy, like Vietnam and Thailand, are the most politically resistant to educational reform, suggesting that much of the talk is simply hot air.

If we stipulate that policy changes are needed to allow middle-income countries to achieve their growth potential, it would hardly seem that middle-income countries are caught in a 'trap'. If all that is needed to restore growth to its long-term potential is to abandon growth-inhibiting policies in favour of growth-promoting ones, then where is the trap? Just change policy!

But what if the policy changes that are needed to make a middle-income country more efficient and dynamic require policymakers (or politicians) to give up discretionary power to grant licenses, land-use rights, government procurement contracts and to direct credit to favoured enterprises and individuals? In other words, what if the policy changes needed to make the economy grow faster are not in the self-interest of rent-seeking authorities or politicians? Then a country is truly in a trap, but one that is political in nature, not economic.

How can countries escape from such a political trap? There is no easy answer. If there were, it would not be a trap. EAFQ

James Riedel is William L. Clayton Professor of International Economics, Johns Hopkins University-SAIS. Pham Thi Thu Tra is Lecturer, Royal Melbourne Institute of TechnologyVietnam. 
SHEKHAR SHAH

AND

RAJESH CHADHA

NDIA, the world's third largest

economy measured in purchasingpower parity terms, became a middleincome country in 2007. It has one of the world's youngest populations, with some 260 million people below the age of 25 , and its economy is once again growing fast-at 7 per cent it was one of the world's fastest-growing economies as of August 2015.

But will it grow rich before it grows old? India's economic growth in the years before the global financial crisis was also spectacular and reduced poverty substantially. But India is likely to remain a lower-middle-income country for at least the next 15 years. India has one of the world's largest concentrations of poor people, with more than 723 million people in 2011 living on less than US\$2 a day.

Part of the problem facing policymakers is India's astonishing diversity. Some states in the Union, like Haryana and Tamil Nadu, are solidly middle income. Others, like Bihar and Uttar Pradesh, would be among the world's poorest countries, were they independent. This means that as India confronts problems that are typically thought of as characterising low-income countries, it may also be forced to consider the kinds of policy challenges that bedevil middle-income countries.

India will need to start thinking about how it will compete in a rapidly changing landscape of manufacturing, global commerce and skillsets shaped by global supply chains, distributed sourcing and processing, and disruptive technologies not yet invented. Its low female labour force participation rate-around 33 per cent in 2012, compared with an East Asian average of 63 per cent-must be addressed. Its innovation and education supply chains will require large strategic investments, and its intellectual property regime to be rethought.

But as important as these long-term challenges are to India's escaping the middle income trap-the tendency of once fast growing countries to falter and remain stuck in middle income territory-the necessity of escaping its low-income traps is, if anything, even more pressing.

Manufacturing has traditionally been the sector that contributes most strongly to economic growth in

States with overly

restrictive laws have

experienced weaker

industrial growth and

have benefited less from

investment delicensing developing countries like India. But there are some disturbing headwinds that will make progress in this area very difficult without concerted policy action.

Though India ought to have a comparative advantage in low-skilled labour-intensive manufacturing, currently the formal, registered manufacturing sector in India uses skilled labour more intensively. Either the sector will have to change in order to absorb a vast, informal labour force, or manufacturing will struggle to provide the productive employment opportunities India sorely needs. In addition, growth in registered manufacturing as a share of output seems to have stalled well before much of India has fully industrialised. Some recent estimates put out by the government in its 2014-15 Annual Economic Survey show that only in Gujarat and in Himachal Pradesh is registered manufacturing's share of adding value increasing.

Why has growth in this sector remained so sluggish in a country where labour is so abundant? The failure to liberalise factor marketsand in particular labour and land markets-is often blamed.

There are more than 140 overlapping labour laws in India: 44 at the federal and about 100 at the state level. States with overly restrictive laws have experienced weaker industrial growth and have benefited less from investment delicensing. This burdensome regulatory environment is part of the reason for India's huge 
informal labour market.

Rational and fair land acquisition is a precondition for large-scale investment in growth-supporting public infrastructure. The law that governed this area of the economy was until 2013 a relic of British imperial legislation, one that provided very few protections for landowners. The new Land Acquisition, Rehabilitation and Resettlement Act introduced by the last government, however, tipped the scales dramatically in favour of landowners, making land acquisition for public purposes extremely difficult. The Modi government has struggled with the parliamentary passage of a new land bill, and while it has had a temporary ordinance in place, this is now being allowed to lapse, and fair, settled, long-term land acquisition will remain difficult until its legal basis is settled.

The political economy of reform in both areas is difficult, given the regulatory overlap with different levels of government. The Modi government's plan of decentralising policymaking, which feeds off the recommendations of the 14th Finance Commission and has been backed by a large increase in the states' share of tax revenue, should provide substantial incentives for states to implement reforms themselves in order to compete for investment.

More broadly, the task facing Indian reformers will be made more difficult by three factors that were not faced by other rapid industrialisers in the region. One is the political economy of a large but underdeveloped country. India's democracy is vibrant, but the sheer size of the poor population means that there is a constant temptation for policymakers to focus their attention on spending tax revenues on handouts rather than on stoking economic growth in order

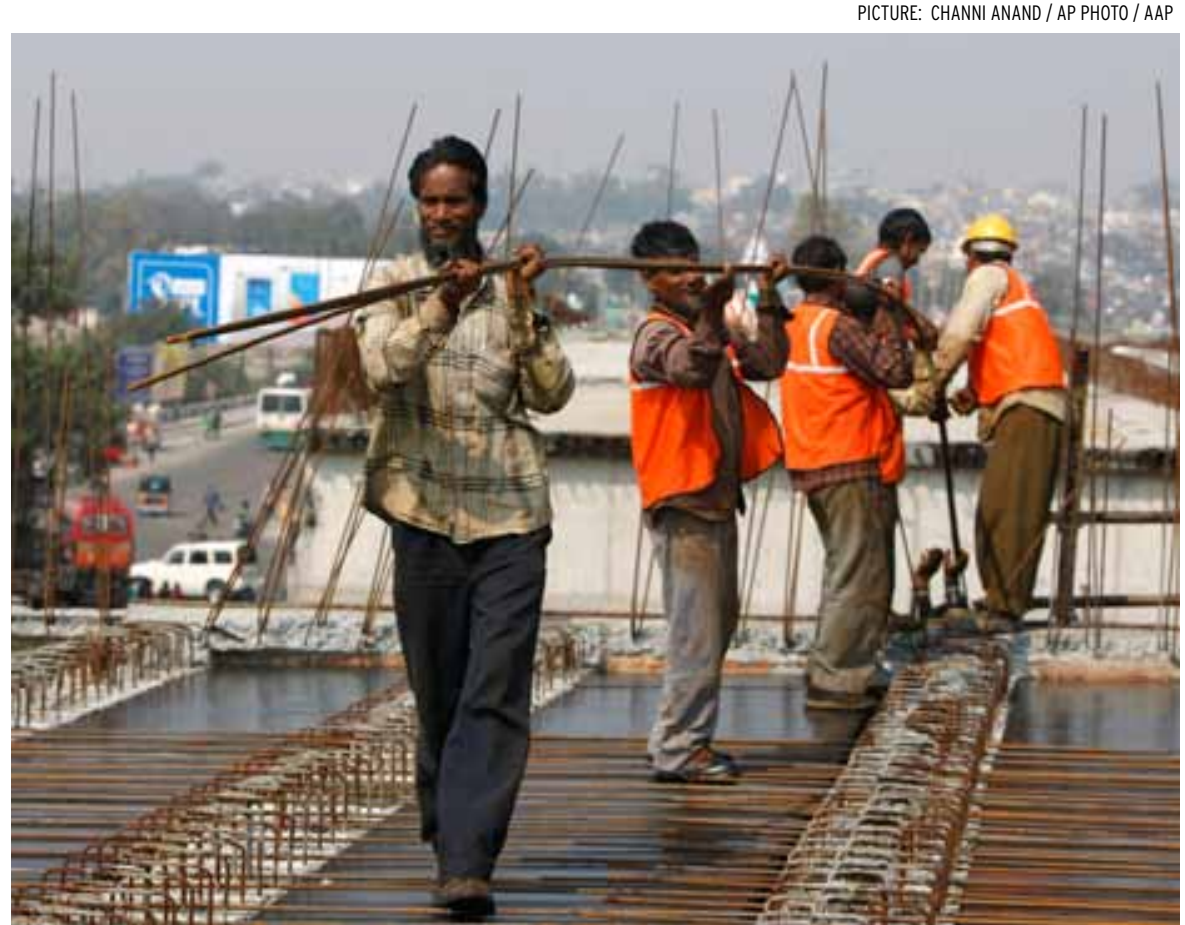

Workers laying reinforcing at a overpass bridge in Jammu in January 2016. Fair land acquisition is a precondition for large-scale investment in growth-supporting public infrastructure in India.

to create jobs that lift people out of poverty.

Another is the disorderly, fragmented global trading environment, with the kind of open multilateralism that facilitated growth in East Asia rapidly giving way to a thicket of preferential deals and trading blocs. And India must also industrialise at the same time as the world is trying to wean itself off greenhouse gas-emitting energy sources and technologies. This is a constraint that did not face countries such as Japan and South Korea during their development. India must use its late-comer advantage to turn challenge into opportunity.

In all, India's policymakers face a formidable set of challenges that span the gamut of economic development. The Modi government has shown that it understands better than any government before it the scale and breadth of the task at hand. But, like its predecessors, it runs the risks of getting submerged in the many pressing day-to-day issues that confront it-and of allowing its rhetoric to run ahead of its results.

What is needed is a small, tightly organised, but empowered group of policymakers, policy researchers and even younger politicians who are charged with thinking about India's future and the policy strategies required to secure prosperity and productivity. Such a group should not seek to put out the daily fires that beset every government, but apply its strategic reasoning to all current policies and programs under review, and to new ones that no one is yet thinking about. EAFO

Dr Shekhar Shah is Director-General of the National Council of Applied Economic Research (NCAER), New Delhi.

Dr Rajesh Chadha is the Senior Research Counsellor at NCAER. 


\section{What institutions do countries need to keep growing?}

\section{DAVID DOLLAR}

$\mathbf{T}$ HE notion of a 'middle income trap' has entered the lexicon of policymakers in emerging markets in Asia and elsewhere. Many leaders of countries that have experienced fast growth-such as Chinese Premier Li Keqiang-worry that economic growth will come off the boil as their countries reach middle-income status.

Growth for virtually all advanced economies was slower in the $2000 \mathrm{~s}$ than in the 1990s; meanwhile growth rates in poor and middle-income countries accelerated. But there is a lot of variation in these broad trends, especially for the middle-income countries. Some of the latter have seen very impressive growth spurts, while others have stagnated.

What explains why some countries grow quickly and others languish? There is a strong empirical relationship between the quality of institutions (as measured by the World Governance Indicators' Rule of Law index) and economic growth. But institutional quality does not change very much from year to year or sometimes even from decade to decade, which makes it hard to explain why countries have periods of high growth followed by low growth (or vice versa).

Institutions which are well-suited to one phase of economic development may be ill-suited to another. One way to resolve the paradox of persistence of institutions and non-persistence of growth rates is to focus on the quality of institutions relative to the level of development. It turns out this can help explain why China and Vietnam, for instance, have seen such high growth in recent times: they have relatively low institutional quality in an absolute sense, but they have aboveaverage quality institutions given their stage of development, which might, for instance, help to attract foreign investment to China or Vietnam rather than other Asian countries with similarly low wage levels but weaker institutions.

Another question is whether authoritarian institutions are better for economic growth than democratic ones. It may depend on the stage of a country's development. When we look at the historical experience, in countries that have a per capita income below US $\$ 8000$, authoritarian institutions seem more conducive to growth. But at higher levels of income, democratic countries are likely to see

\section{At the stage of}

\section{development at which}

\section{China now finds itself,}

South Korea and Taiwan

were on the way to

becoming more or less

free societies higher growth than authoritarian ones. Why might this be so?

One explanation might be that at low levels of income, the economic priority of government should be to establish basic law and order and an environment in which private investment, including foreign investment, can operate. This is a catch-up stage in which innovation is not yet particularly relevant. But the usual economic strategy for authoritarian governments relies on capital accumulation, which becomes less effective as countries get richer. When an economy reaches the point where acquiring more and more capital is no longer sufficient for rapid growth, the need for political and economic institutions that promote competition, innovation and productivity growth becomes paramount.

Interestingly, it is about at the US $\$ 8000$ per capita GDP mark that two of East Asia's great developmental success stories, Taiwan and South Korea, were also becoming free and open polities. By the early 1980s for Taiwan and the mid-1980s for South Korea, a move had been made away from authoritarian institutions, a change that continued until both reached fully democratic status as measured by Freedom House's civil liberties metric.

Of the Asian countries that have witnessed rapid growth recently, Vietnam has shown some steps towards political liberalisation, with its civil liberties score moving to five, which is slightly better than either 
South Korea or Taiwan at the same stage of development. But Vietnam is entering the stage of development where the line of thinking presented above implies a need for further political reform. Greater freedom will be necessary to strengthen property rights and the rule of law in order to bring about an environment for innovation and productivity growth.

China, on the other hand, has largely eschewed political reform. Although he has placed a lot of emphasis on the idea of implementing the 'rule of law' in China, President $\mathrm{Xi}$ Jinping has made it abundantly clear that he wants to pursue economic reform without political liberalisation; some observers even point to backsliding in recent years on the question of freedom of ideas and debate. The historical evidence would suggest that this will weigh on the growth of the Chinese economy in the future. At the stage of development at which China now finds itself, South Korea and Taiwan were on the way to becoming more or less free societies.

Of course, just because no authoritarian country (apart from oil producers and, depending on how you classify it, Singapore) has reached more than 35 per cent of US GDP per capita does not mean that it will be impossible for China to do so. But the historical evidence should caution Chinese policymakers against thinking that the kind of political institutions that have facilitated China's astonishing growth up to now will be sufficient or optimal for the next stage of its development. EAFQ

David Dollar is Senior Fellow, John L. Thornton China Center, Brookings Institution. He was the former World Bank Country Director for China and Mongolia in the East Asia and Pacific Region.

\section{Middle-income} nations must learn to trust the market

SHIRO ARMSTRONG

AND

TOM WESTLAND

A FTER a turbulent 2015, China's major stock exchanges took another hit in January. Chinese authorities have in the past clumsily tried to stop the free fall in markets with various degrees of success. But for China to avoid a middle income trap and become a high-income country, it will need to develop and trust the markets instead of distorting them with unsustainable growth, just like its Northeast Asian neighbours did. The notion of a 'middle income trap' has gained currency in recent years and focused attention on the policies that facilitate economic growth in middle-income countries.

East Asia is home to a number of economies that have managed to graduate from middle-income status to be classified into the high-income group of economies. Japan, South Korea, Taiwan and Singapore all caught up to technologically advanced countries and their peoples enjoy high incomes.

Yet globally only 13 of 101 middleincome countries have been able move to high-income status since 1960. China and other countries in Southeast Asia have succeeded in emulating rapid catch-up growth out of poverty but have yet to make the transition to high income. Thailand and Malaysia appear stuck in the middle. India, the Philippines and Indonesia are at a lower level of development but are growing fast, and policymakers are already beginning to contemplate how they can join the ranks of the world's advanced economies.

So how can countries escape the trap?

Openness to international trade and investment-such as lower tariffs and openness to foreign investmentis widely recognised as a necessary condition for rapid catch-up growth in developing countries. But these conditions are unlikely to be sufficient for countries that wish to move to high income.

As countries approach the global technology frontier, institutions that encouraged growth (or at least did not slow it) in the catch-up phase can begin to hinder economic growth. Often these involve government intervention-including regulation, cheap credit and direct government ownership-in favour of specific sectors or firms. Continuing a path of economic growth that will lead countries out of the middle income trap requires institutions that foster firm entry and exit, competitive domestic product and factor markets, and well-developed financial markets that allocate capital efficiently.

As middle-income countries are defined by their distance from the 


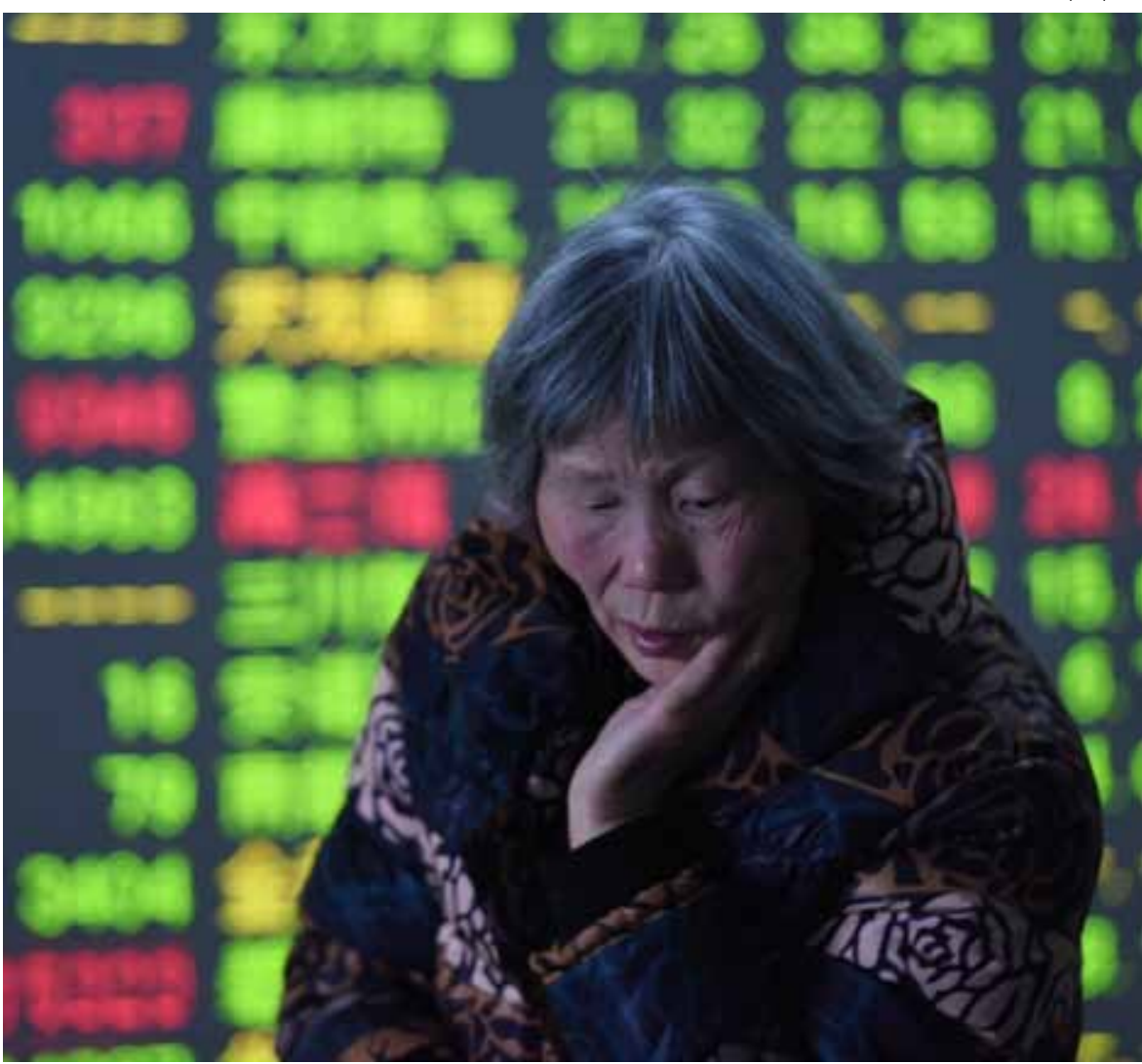

Green signals falling prices and rising concerns for this investor in Hangzhou, China, in February 2016. Despite ups and downs, well-developed financial markets allocate capital efficiently.

global technology frontier, the ability to upgrade, catch up and innovate is important to their closing that distance. To reach the frontier, countries need to be open to ideas and have institutions that allow for more complex interactions across the economy. That would seem to include good governance characterised by decentralised economic decisionmaking.

Institutions suited to growth and development differ at different stages of development. Those considered second-best practice such as industrial policy or quick fixes and market suppression that substitutes for functioning markets may serve developing countries sufficiently well, and Asian countries demonstrate that this is the case during catch-up growth. Some barriers to entry and the existence of economic rents, while inefficient in theory, may stimulate entrepreneurship, investment and exports in countries at very low levels of development. Yet these secondbest policies become a hindrance once a country moves closer to the technology frontier.

In particular, strong growth in middle-income countries requires well-functioning capital markets. Developing East Asian economies were no different from other developing countries in having shallow, underdeveloped capital markets. Northeast Asian economies, and China in particular, overcame some of those constraints with capital market distortions coupled with export-favouring industrial policies. Yet as China grows richer and more technologically advanced, and hence as innovation-based growth becomes more important, it will need to reform underlying market failures in capital markets. The experience of countries in the region tends to show that middle-income countries that have less distorted capital markets relative to their stage of development tend to grow faster.

This doesn't mean complete financial deregulation is the answeras Asian countries learnt in the Asian financial crisis and we all learnt from America more recently, rigorous prudential regulation is essential. But the regulations governing capital markets in middle-income countries should not be tilted in favour of preferred sectors or well-connected firms.

The problem for many of Asia's middle-income countries looking to graduate to high-income status is that of generating the political will to make the necessary reforms. Favoured firms will fight bitterly to resist changes that threaten their market power. There is some evidence that democracies are more likely to make the kinds of financial sector reforms that are needed to escape the trap, which may suggest that political structures need to change in the region's middleincome countries.

The middle income trap is an economic phenomenon, but escaping it through deeper openness and financial reform is a political challenge. And it's one that leaders in China, Thailand, Malaysia and other middleincome countries must rise to. EAFQ

\section{Shiro Armstrong is co-director of the} Australia-Japan Research Centre and co-Editor of East Asia Forum at The Australian National University. Tom Westland is a graduate student at the Institut des hautes études internationales et du développement. 

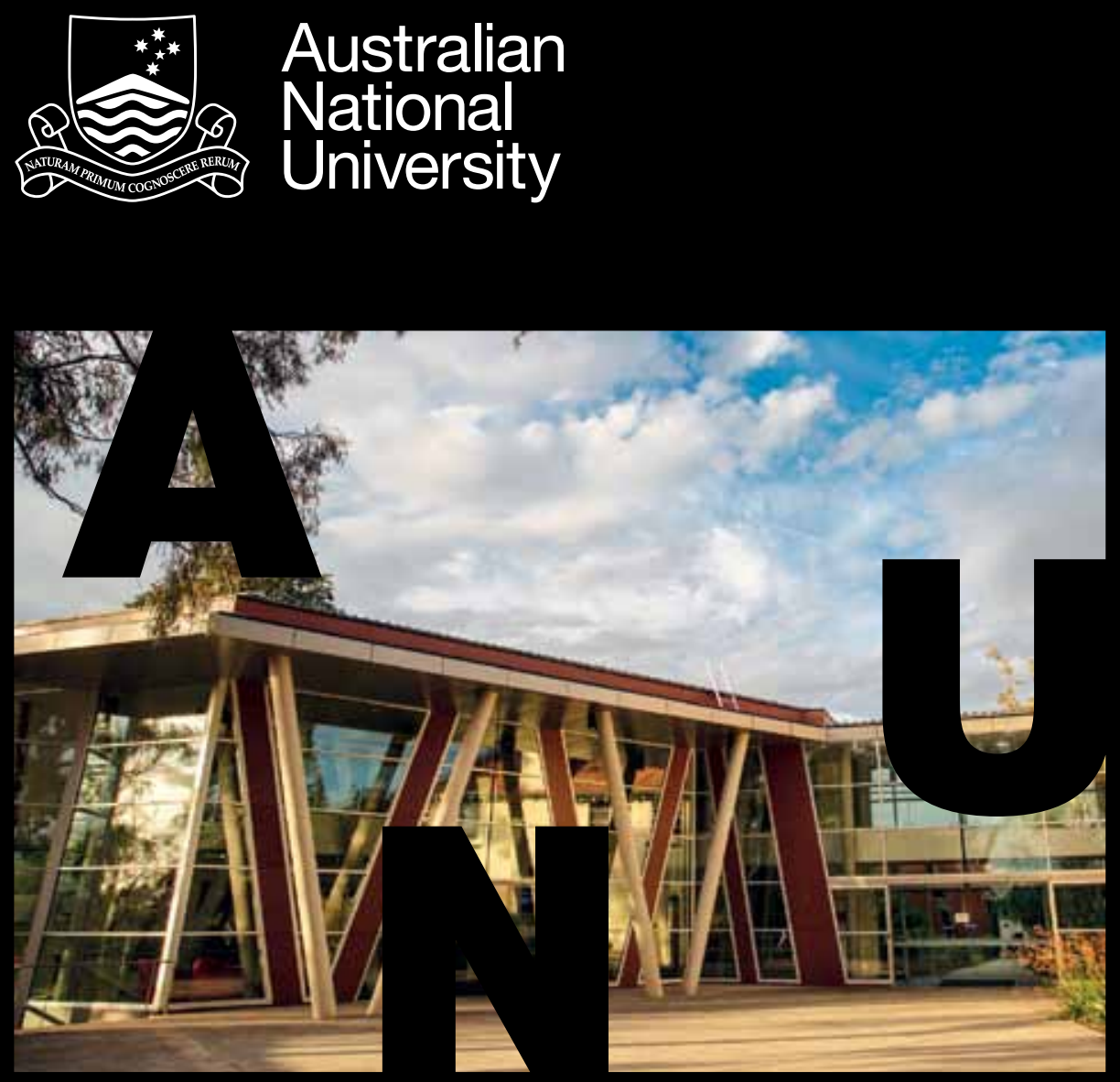

\section{JOIN THE PUBLIC POLICY THOUGHT LEADERS}

$\begin{array}{ll}\begin{array}{l}\text { ANU Crawford School } \\ \text { of Public Policy is }\end{array} & \begin{array}{l}\text { Crawford School staff and } \\ \text { visitors are active on government } \\ \text { renowned for world-class } \\ \text { research, education }\end{array} \\ \begin{array}{l}\text { coles across government, } \\ \text { and policy engagement, } \\ \text { leading and shaping }\end{array} & \begin{array}{l}\text { Join our vibrant policy community, } \\ \text { which brings together scholars, }\end{array} \\ \text { policy thinking in Australia, } & \text { students, policy-leaders and } \\ \text { Asia and the Pacific. } & \begin{array}{l}\text { policy practitioners from the } \\ \text { public, private and NGO } \\ \text { sectors in Australia, the region } \\ \text { and globally. }\end{array}\end{array}$

Explore your options for research partnership, postgraduate study and executive education in the following:

$>$ Public policy

$>$ Public administration

$>$ Applied economics

$>$ International development

$>$ Environmental and resources management, and

$>$ National security. 